\title{
Chronic Alcohol Disrupts Dopamine Receptor Activity and the Cognitive Function of the Medial Prefrontal Cortex
}

\author{
Heather Trantham-Davidson, ${ }^{1}$ Elizabeth J. Burnett, ${ }^{1}$ Justin T. Gass, ${ }^{1}$ Marcelo F. Lopez, ${ }^{1}$ Patrick J. Mulholland, \\ Samuel W. Centanni, ${ }^{1}$ Stan B. Floresco, ${ }^{2}$ and L. Judson Chandler ${ }^{1}$ \\ ${ }^{1}$ Department of Neurosciences, Medical University of South Carolina, Charleston, South Carolina 29425 and ${ }^{2}$ Department of Psychology and Brain Research \\ Centre, University of British Columbia, Vancouver, British Columbia, Canada V6T1Z4
}

\begin{abstract}
Dopamine (DA) receptors in the medial prefrontal cortex ( $\mathrm{mPFC}$ ) exert powerful effects on cognition by modulating the balance between excitatory and inhibitory neurotransmission. The present study examined the impact of chronic intermittent ethanol (CIE) exposure on cognitive function and DA receptor-mediated neurotransmission in the rat mPFC. Consistent with alterations in executive function in alcoholics, CIE-exposed rats exhibited deficits in behavioral flexibility in an operant set-shifting task. Since alterations in dopaminergic neurotransmission in the mPFC have been implicated in a number of behavioral disorders including addiction, studies were then performed in the adult acute slice preparation to examine changes in DA receptor function in the mPFC following CIE exposure. In slices obtained from control rats, DA receptor stimulation was observed to exert complex actions on neuronal firing and synaptic neurotransmission that were not only dependent upon the particular receptor subtype but also whether it was a pyramidal cell or a fast-spiking interneuron. In contrast to slices from control rats, there was a near complete loss of the modulatory actions of D2/D4 receptors on cell firing and neurotransmission in slices obtained immediately, 1 and 4 weeks after the last day of CIE exposure. This loss did not appear to be associated with changes in receptor expression. In contrast, CIE exposure did not alter D1 receptor function or mGluR1 modulation of firing. These studies are consistent with the suggestion that chronic alcohol exposure disrupts cognitive function at least in part through disruption of D2 and D4 receptor signaling in $\mathrm{mPFC}$.
\end{abstract}

Key words: alcohol; cognitive; D2/D4; dopamine; mGluR1; PFC

\section{Introduction}

Alcoholics exhibit cognitive impairments that manifest as increased risk taking, poor decision making, and loss of inhibitory control over behavior. Recent studies in humans have revealed that multiple cognitive domains, particularly executive functions regulated by the prefrontal cortex (PFC), are perturbed during the first year of abstinence and then show signs of recovery with continued abstinence (Bergman et al., 1998; Sullivan et al., 2000; Wölwer et al., 2001; Tedstone and Coyle, 2004; Rando et al., 2011; Sabia et al., 2011). Importantly, these deficits are believed to greatly increase vulnerability to relapse and thus are significant impediments to the development of effective treatment of this chronic relapsing disorder (Finn et al., 1999; Wölwer et al., 2001). Reversing cognitive deficits in abstinent alcoholics may restore inhibitory processes and reduce the incidence of relapse to uncontrolled drinking (Campanella et al., 2009, 2011; Myrick et al., 2007).

Received Feb. 8, 2013; revised Jan. 27, 2014; accepted Jan. $29,2014$.

Author contributions: H.T.-D., E.J.B., J.T.G., P.J.M., S.B.F., and L.J.C. designed research; H.T.-D., E.J.B., J.T.G., M.F.L., and S.W.C. performed research; H.T.-D., E.J.B., and J.T.G. analyzed data; H.T.-D. and L.J.C. wrote the paper.

This work is supported by National Institutes of Health Grants R01AA010983 and U01AA019967 (L.J.C.), K99AA020537 (J.T.G.), T32AA007474 (S.W.C.), F31022836 (E.J.B.), and CIHR MOP102478 (S.B.F.).

Correspondence should be addressed to Heather Trantham-Davidson, PhD., Department of Neurosciences, Medical University of South Carolina, Charleston, SC 29425. E-mail: tranthah@musc.edu.

DOI:10.1523/JNEUROSCI.0623-13.2014

Copyright $\odot 2014$ the authors $\quad 0270-6474 / 14 / 343706-13 \$ 15.00 / 0$
While there is good evidence that chronic alcohol exposure results in cognitive dysfunction, little is known about how neurotransmission and neural network activity in the PFC are adversely impacted by chronic alcohol. The neural networks that underlie decision making and cognitive control of behavior are critically dependent upon dopamine (DA; Floresco and Magyar, 2006). While neuropathology such as neuronal loss may contribute to certain aspects of alcohol-induced cognitive dysfunction, protracted neurochemical changes specifically within the PFC may also play a primary role. Appropriate activation of neural networks in the PFC requires an optimal balance between activation of D1- and D2-like DA receptors (Arnsten et al., 1994; Gao et al., 2003; Cools and D'Esposito, 2011). DA neurotransmission in the PFC regulates cognitive function, and the loss of cognitive ability in alcoholics may relate to alterations in D2 receptor expression in the dorsolateral PFC (Volkow et al., 1996, 2002). Furthermore, reduced D2 receptor function increases alcohol consumption in animal models (Bice et al., 2008; Morganstern and Tejani-Butt, 2010) and enhances susceptibility of developing alcoholism in humans (Kraschewski et al., 2009; van der Zwaluw et al., 2011). Conversely, high levels of D2 receptors have the opposite effect in that they reduce drinking and the susceptibility to developing alcoholism (Volkow et al., 2006; Kraschewski et al., 2009). While the effects of acute and chronic alcohol on DA transmission have been widely studied in brain regions implicated in the rewarding effects of drugs, relatively few have focused 
on the effect of alcohol on DA neurotransmission in the PFC. Accordingly, the present study was designed to assess the manner in which chronic ethanol may affect D1, D2, and D4 signaling in PFC, and investigate how this can disrupt executive functions regulated by the frontal lobes.

\section{Materials and Methods}

\section{Animals}

Male Long-Evans rats (250-275 g upon arrival; Harlan) were housed individually in standard polycarbonate cages. Access to food and water in the home cage was continuous throughout the experiment except during behavioral testing. The animal colony room was maintained on a $12 \mathrm{~h}$ light/dark cycle with lights off at 09:00, and experimental testing was performed during the dark portion of the cycle. All experimental procedures were conducted with the approval of the Institutional Animal Care and Use Committee at the Medical University of South Carolina, and within guidelines set forth by the National Research Council's Guideline for the Care and Use of Mammals in Neuroscience and Behavioral Research (2003).

\section{Chronic intermittent ethanol exposure model}

Rats were single housed under a $12 \mathrm{~h}$ reverse light/dark cycle, with continuous access to food and water. Animals in all groups were $70-85$ days old at initiation of treatment and between 92 and $107 \mathrm{~d}$ old when experiments were performed. Chronic intermittent ethanol (CIE) exposure followed procedures as previously described (O'Dell et al., 2004). In brief, rats were exposed to ethanol vapor or air in inhalation chambers for $14 \mathrm{~h} / \mathrm{d}$ for 15 consecutive days (from 6:00 PM to 8:00 AM) with $10 \mathrm{~h}$ periods of withdrawal separating each exposure. Chamber ethanol concentrations were measured daily and blood samples were collected from all animals by tail vein puncture on exposure days 2, 6, 10, and 15 for measurement of blood ethanol concentration (BEC; target range of $250-$ $300 \mathrm{mg} \%$ ). Intoxication ratings were assessed using a similar scale to the one described previously (Nixon and Crews, 2002). In brief, the rats were scored according to the following behaviors: $1=$ No signs of intoxication; 2 = Slightly intoxicated (slight motor impairment); 3 = Moderately intoxicated (obvious motor impairment but able to walk); $4=$ Highly intoxicated (dragging abdomen, loss of righting reflex); 5 = Extremely intoxicated (loss of righting reflex and loss of eye blink reflex).

\section{Measurement of BEC}

Immediately following collection of blood from the tail vein, the blood was centrifuged at $10,000 \times g$ for $10 \mathrm{~min}$ to obtain a plasma supernatant, which was then stored at $4^{\circ} \mathrm{C}$ for a maximum of $24 \mathrm{~h}$. Next, $10 \mu \mathrm{l}$ of plasma was used for determination of ethanol levels using a colorimetric enzymatic assay as described previously (Prencipe et al., 1987).

\section{Operant set-shifting procedure}

A total of 20 rats were trained in the set-shifting task. However, three rats were removed from the study because they failed to successfully acquire the operant task and one additional rat was removed due to procedural error, leaving a total of 16 rats $(n=9$ control, $n=7$ CIE). We used 12 operant chambers $(30.5 \times 24 \times 21 \mathrm{~cm}$; Med Associates $)$ enclosed in sound-attenuating boxes. Boxes were equipped with a fan to provide ventilation and to mask extraneous noise. Each chamber was fitted with two retractable levers, one located on each side of a central receptacle where $20 \%$ sweetened condensed milk was delivered by a syringe-driven pump. An LED stimulus light was positioned centrally above each lever and served as a stimulus for visual-cue discrimination learning. Each chamber was illuminated by a single $100 \mathrm{~mA}$ house light located in the top center of the wall opposite the levers. Chambers were interfaced with a PC that controlled the experimental session and recorded data using commercially available software (Med Associates; MED-PC IV). Rats were food restricted to maintain $90 \%$ of original body weight at the beginning of behavioral training in the set-shifting task and this restriction was maintained until the end of behavioral testing.

The operant set-shifting procedure was based upon the method previously described and characterized by Floresco et al. (2008). The task consisted of three distinct phases as described below: a Training phase in which the rat learned to lever press and their side preference is determined, a Visual-cue discrimination phase in which they learned to respond to a visual cue where the correct lever was indicated by a stimulus light located directly above it, and a Response discrimination phase in which the rat was required to shift its discrimination strategy from the previously learned visual-cue rule to an egocentric spatial location rule wherein the correct response was independent of the visual-cue light (e.g., always press the left lever).

Training phase. During this phase, rats were trained on a fixed ratio 1 schedule of reinforcement. At the beginning of the first training session (30 $\mathrm{min}$ ), both levers were extended and the house and receptacle lights are illuminated. Each lever press activated a syringe pump for $1.5 \mathrm{~s}$ to deliver $\sim 45 \mu \mathrm{l}$ of $20 \%$ sweetened condensed milk (Carnation) into the reward receptacle, accompanied by a $65 \mathrm{~dB}$ tone. Rats received daily 30 min sessions until stable responding was achieved, defined as receiving at least 50 reinforcers during a session for 2 consecutive days. Training then proceeded to the next stage in which a lever press resulted in reinforcer delivery accompanied by retraction of the levers and extinguishing of the lights for $20 \mathrm{~s}$ before a new trial began. The rats remained in this phase of training for $30 \mathrm{~min}$ sessions per day until they were receiving 50 reinforcers per session. In the final training stage, the rat learned that it must respond within a discrete period of time to receive a reward. One lever (randomly chosen) was extended and the house and receptacle lights were illuminated throughout the session. If the rat pressed the lever within $10 \mathrm{~s}$ of lever extension, the reward was delivered and the lever was retracted for $15 \mathrm{~s}$ with the house lights off before a new trial began. If the rat failed to respond within the $10 \mathrm{~s}$, the lever was retracted and no reward was delivered. The house lights were turned off and the lever was retracted for $15 \mathrm{~s}$ before a new trial began. The rats received 100 trials per session and had to earn 50 reinforcers per session for 2 consecutive days before progressing to the next stage of the task. Next, the side preference for each rat was determined. At the beginning of the session, both levers were extended and the house lights were illuminated. The receptacle light remained on throughout the trial. If the rat pressed one of the levers within $10 \mathrm{~s}$ of its extension, the levers were retracted for $20 \mathrm{~s}$ and the syringe pump activated for $0.5 \mathrm{~s}$ to deliver $\sim 15 \mu \mathrm{l}$ of reward accompanied by the tone. If the rat fails to make a response within the $10 \mathrm{~s}$ response window, the lever is retracted for $20 \mathrm{~s}$ without reward delivery. The lever on which the rat responds most frequently during a $30 \mathrm{~min}$ session is then designated as the preferred side for that animal.

Visual-cue discrimination. The visual-cue discrimination required the rat to respond on the lever that had a visual-cue stimulus light illuminated above it. At the beginning of the session, both levers were retracted and the chamber and receptacle lights were turned off. Every trial began with illumination of the stimulus light above one of the levers. After $5 \mathrm{~s}$, the house and receptacle lights were illuminated and both levers were extended into the chamber. A correct response (response on the lever indicated by the stimulus light) resulted in delivery of reward and retraction of both levers for $30 \mathrm{~s}$. An incorrect response or failure to respond with $10 \mathrm{~s}$ resulted in retraction of both levers and lights off for $30 \mathrm{~s}$. Training continued on multiple consecutive days until criterion performance was achieved, which consisted of eight correct trials in a row with a minimum of 30 trials and a maximum of 120 trials within a session. When a rat reached criterion performance for one session, CIE or air exposure treatment began for 15 consecutive days. Following $3 \mathrm{~d}$ of withdrawal from CIE/air exposure, retraining began and rats were trained again so that they reached criterion performance on 4 consecutive days.

Shift to response discrimination. After successful acquisition of the visual-cue discrimination rule, behavioral flexibility was assessed by testing the rats' ability to acquire a new rule. The reward contingency was shifted from the illuminated visual cue to the spatial location of the lever. Therefore, a correct response required the rat to press the lever opposite of their preferred location as determined by the side-bias training and ignore the stimulus light presentation. A press on the inactive lever was recorded as an error and no reinforcer was delivered. All other aspects of the procedure were identical to the previous trials, where criterion performance was set at 8 consecutive correct trials. 


\section{Progressive ratio}

To assess a potential change in motivation for food reward induced by CIE, the reinforcing efficacy of the $20 \%$ sweetened condensed milk solution was determined using a progressive ratio (PR) schedule of reinforcement procedure similar to that described by Richardson and Roberts (1996). In this testing procedure, the number of lever presses required to obtain a single delivery of $20 \%$ sweetened condensed milk (fixed rate; FR) was determined by the following equation: responses per reinforcer delivery (rounded to nearest integer $)=\left[5 e^{\text {(reinforcer number } \times 0.2)}\right]-5$ (e.g., FR1, FR2, FR4, FR6, FR9, FR12, FR15, FR20, FR25, FR32, FR40, etc.), where $e$ is the base of the natural log. All PR testing was conducted in $16 \mathrm{~h}$ overnight sessions, and each reinforcer delivery was followed by a $4 \mathrm{~s}$ timeout period, during which additional active lever presses were recorded but produced no programmed consequences. Breakpoint was defined as the number of responses preceding a time when the animal failed to press for at least $1 \mathrm{~h}$. The primary dependent variables measured during each $16 \mathrm{~h}$ session were the number of active and inactive lever presses, the number of reinforcers earned, and the latency for each rat to reach its respective breakpoint.

\section{Electrophysiological recordings}

Acute slices were obtained for electrophysiological recordings from a separate group of rats 7-8 d after their last day of alcohol exposure. Rats were anesthetized with isoflurane, rapidly decapitated, and the brain was immediately removed and placed in a sucrose-based dissection solution consisting of ice-cold dissection artificial CSF (ACSF) solution containing the following (in $\mathrm{mM}$ ): 200 sucrose, $1.9 \mathrm{KCl}, 1.2 \mathrm{Na}_{2} \mathrm{HPO}_{4}, 33$ $\mathrm{NaHCO}_{3}, 6 \mathrm{MgCl}_{2}, 0.5 \mathrm{CaCl}_{2}, 10 \mathrm{D}$-glucose, and 0.4 ascorbic acid. Slices were incubated at $34^{\circ} \mathrm{C}$ for at least $1 \mathrm{~h}$ before recordings in incubation ACSF containing the following (in $\mathrm{mm}$ ): $125 \mathrm{NaCl}, 2.5 \mathrm{KCl}, 1.25$ $\mathrm{NaHPO}_{4}, 25 \mathrm{NaHCO}_{3}, 4 \mathrm{MgCl}_{2}, 1 \mathrm{CaCl}_{2}, 10$ D-glucose, 15 sucrose, 0.4 ascorbic acid, and 2 kynurenic acid, continuously aerated with $5 \%$ carbon dioxide/ $95 \%$ oxygen. After incubation, slices were transferred to a submerged recording chamber, held at $34^{\circ} \mathrm{C}$, and bathed with oxygenated recording ACSF containing the following (in $\mathrm{mm}$ ): $125 \mathrm{NaCl}, 2.5$ $\mathrm{KCl}, 25 \mathrm{NaHCO}_{3}, 2 \mathrm{CaCl}_{2}, 1.3 \mathrm{MgCl}_{2}, 10$ glucose, and 0.4 ascorbic acid. The $\mathrm{pH}$ of all solutions listed above was adjusted to 7.3 using $\mathrm{NaOH}$ and osmolarity was measured to be $\sim 300 \mathrm{mOsm}$.

Recordings were made with a Multiclamp 700B amplifier (Molecular Devices), connected to a computer running Windows XP and AxoGraph $\mathrm{X}$ software and later analyzed off-line. All recordings were obtained from pyramidal neurons and fast-spiking (FS) interneurons in Layer $\mathrm{V}$ of the prelimbic (PrL) region of the medial PFC (mPFC; Paxinos and Watson, 2007) identified visually with infrared-differential interference contrast optics and video microscopy.

For current-clamp experiments, recording electrodes (4-6 M $\Omega$ resistance) were filled with a solution containing the following (in mM): 125 potassium gluconate, $20 \mathrm{KCl}, 10 \mathrm{HEPES}, 1$ EGTA, $2 \mathrm{MgCl}_{2}, 2 \mathrm{Na}$-ATP, and 0.3 Tris-GTP, 10 phosphocreatine. The $\mathrm{pH}$ was adjusted to 7.3 using $\mathrm{KOH}$ and osmolarity was measured to be $\sim 285 \mathrm{mOsmol}$. To analyze firing characteristics and intrinsic properties, current steps were applied for $1 \mathrm{~s}$ and increased in $20 \mathrm{pA}$ increments from $-100 \mathrm{pA}$ until the cell fired $8-10$ action potentials for pyramidal neurons. When recording from FS interneurons, spiking occurs at highly variable frequencies and thus the current steps were increased until $>1$ spike was elicited, which usually produced between 3 and 25 action potentials.

For voltage-clamp experiments, recording electrodes (4-6 $\mathrm{M} \Omega$ resistance) were filled with a solution containing the following (in $\mathrm{mM}$ ): 135 $\mathrm{CsCl}, 2 \mathrm{MgCl}_{2}, 10 \mathrm{HEPES}, 1$ EGTA, $4 \mathrm{NaCl}, 2 \mathrm{Na}$-ATP, and 0.3 Tris-GTP, 10 phosphocreatine. QX-314 $\mathrm{Cl}^{-}(1 \mathrm{~mm})$ was added to pipettes to block voltage-sensitive sodium channels from generating action potentials. The $\mathrm{pH}$ was adjusted to 7.3 using $\mathrm{KOH}$ and osmolarity was measured to be $\sim 285 \mathrm{mOsmol}$. Series resistances $(<20 \mathrm{M} \Omega)$ and input resistances were continually monitored throughout the experiment via a $1 \mathrm{mV}(100$ $\mathrm{ms}$ ) hyperpolarizing pulse. EPSCs and IPSCs were evoked using a tungsten bipolar stimulating electrode placed in layer V within $200 \mu \mathrm{M}$ of the cell being recorded. The stimulating electrode was connected to a Grass S88 stimulator and stimulus isolation unit. An input-output relationship was obtained by varying the intensity of stimulation from an amount that produced no response up to an amount that produced a response of maximal amplitude regardless of further increases in stimulus intensity. The stimulus intensity was then reduced to elicit a response that was $\sim 75 \%$ of the maximal amplitude, and evoked responses were then measured at holding potentials from $-80 \mathrm{mV}$ to $+40 \mathrm{mV}$ in $10 \mathrm{mV}$ increments. Evoked NMDA (eNMDA) and evoked AMPA currents were elicited by focal electrical stimulation in the presence of $100 \mu \mathrm{M}$ picrotoxin and either CNQX $(10 \mu \mathrm{M})$ or DL-APV $(50 \mu \mathrm{M})$, respectively. GABA currents were evoked in the presence of both CNQX and DL-APV. During these experiments, sEPSCs and sIPSCs were also collected for analysis. The Kv3.1/3.2 current was measured using a modified K-gluconate internal solution containing the following (in $\mathrm{mM}$ ): 125 potassium gluconate, $20 \mathrm{KCl}, 10 \mathrm{HEPES}, 1$ EGTA, $10 \mathrm{BAPTA}, 2 \mathrm{MgCl}_{2}$, $2 \mathrm{Na}-\mathrm{ATP}$, and 0.3 Tris-GTP, 10 phosphocreatine. The addition of BAPTA served as a calcium chelator to limit the contribution of $\mathrm{Ca}^{2+}$-activated $\mathrm{K}^{+}$currents to $I_{K}$. In addition, $200 \mu \mathrm{M}$ tetraethylammonium (TEA) and $1 \mu \mathrm{M}$ tetrodotoxin were added to the external solution to isolate the Kv3.1/3.2 component of $I_{K}$ and block $\mathrm{Na}^{+}$currents, respectively.

\section{Western blotting}

The expression of NMDA receptor subunits in the PrL mPFC of control and CIE-exposed rats was analyzed by Western blotting. In brief, rats were rapidly killed by decapitation and brains were immediately immersed for 1-2 min in ice-cold PBS, pH 7.4. Brains were sectioned into 1-mm-thick coronal slices using an adult rat brain matrix (ASI Instruments) and punches were taken from the dorsal mPFC, which contained primarily the PrL region. Postsynaptic density-enriched fractions were prepared as previously described (Mulholland et al., 2011). An aliquot of each sample was diluted with NuPAGE $4 \times$ LDS sample loading buffer (Invitrogen; $\mathrm{pH}$ 8.5) containing $500 \mathrm{~mm}$ dithiothreitol, and samples were denatured for $10 \mathrm{~min}$ at $70^{\circ} \mathrm{C}$. Five micrograms of each sample was separated using the Bis-Tris ( $375 \mathrm{~mm}$ resolving buffer and $125 \mathrm{~mm}$ stacking buffer, $\mathrm{pH} 6.4 ; 7.5 \%$ acrylamide) discontinuous buffer system with MOPS electrophoresis buffer (50 mM MOPS, $50 \mathrm{~mm}$ Tris, $0.1 \%$ SDS, and $1 \mathrm{~mm}$ EDTA, pH 7.7). Protein was then transferred to Immobilon-P PVDF membranes (Millipore) using a semidry transfer apparatus (BioRad). After transfer, blots were washed with PBS containing $0.1 \%$ Tween 20 (PBST) and then blocked with PBST containing 5\% nonfat dried milk (NFDM) for $1 \mathrm{~h}$ at room temperature with agitation. The membranes were then incubated overnight at $4^{\circ} \mathrm{C}$ with primary antibodies directed against NMDA receptor subunits (GluN1, 1:4000, BD PharMingen; GluN2B, 1:1000, NeuroMab, Antibodies and University of California Davis; GluN2A, 1:1000, Millipore) diluted in PBST containing 0.5\% NFDM and washed in PBST before $1 \mathrm{~h}$ incubation at room temperature with horseradish peroxidase-conjugated secondary antibodies diluted 1:2000 in PBST. Membranes received a final wash in PBST and the antigen-antibody complex was detected by enhanced chemiluminescence. The band corresponding to the appropriate subunit was quantified by mean optical density using computer-assisted densitometry with ImageJ v1.41 (National Institutes of Health).

\section{Receptor autoradiography}

$\mathrm{D} 2$ and $\mathrm{D} 4$ receptor density and D2 receptor-stimulated GTP $\gamma \mathrm{S}$ binding was determined in the $\mathrm{mPFC}$ of control and CIE-exposed rats using in vitro receptor autoradiography. In brief, control and 1 week withdrawn CIE rats were transcardially perfused with ice-cold PBS, pH 7.4. The brain was then rapidly removed from the skull and immediately frozen on dry ice. The frontal cortex was sectioned coronally at $20 \mu \mathrm{m}$ using a cryostat maintained at $-20^{\circ} \mathrm{C}$. Sections containing the mPFC were thaw mounted to Frost Plus slides and immediately placed on wet ice. The slides were subsequently placed in a desiccator overnight at $4^{\circ} \mathrm{C}$ and then stored at $-80^{\circ} \mathrm{C}$ until their use in the assays. D2 receptor density was determined using the $\mathrm{D} 2$ receptor antagonist $\left[{ }^{3} \mathrm{H}\right]$ raclopride (PerkinElmer) as previously described (Beveridge et al., 2009). Sections were preincubated for $20 \mathrm{~min}$ at room temperature in $50 \mathrm{~mm}$ Tris- $\mathrm{HCl}$ containing $120 \mathrm{~mm} \mathrm{NaCl}$ and $5 \mathrm{~mm} \mathrm{KCl}, \mathrm{pH}$ 7.4. Total binding was determined by incubation for $30 \mathrm{~min}$ in the same buffer containing $2 \mathrm{nM}\left[{ }^{3} \mathrm{H}\right]$ raclopride $(60.0 \mathrm{Ci} / \mathrm{mmol})$ and $5 \mathrm{~mm}$ ascorbic acid. Nonspecific binding was determined in the presence of $1 \mu \mathrm{M}(+)$ butaclamol (D2 antagonist). Sections were subsequently washed in ice-cold 
preincubation buffer $(3 \times 5 \mathrm{~min})$ followed by a final rinse in ice-cold deionized water.

D4 receptor density was determined using the D2/D4 receptor antagonist $\left[{ }^{3} \mathrm{H}\right] \mathrm{YM}-09151-2$ (nemonapride; PerkinElmer) according to the procedures of Gan et al. (2004). Sections were preincubated for $60 \mathrm{~min}$ at room temperature in $50 \mathrm{~mm}$ Tris- $\mathrm{HCl}$ containing $120 \mathrm{~mm} \mathrm{NaCl}, 5 \mathrm{~mm}$ $\mathrm{KCl}, 2 \mathrm{mM} \mathrm{CaCl}_{2}$, and $1 \mathrm{~mm} \mathrm{MgCl}_{2}$, $\mathrm{pH}$ 7.4. Total binding was determined by incubation for $60 \mathrm{~min}$ in the same buffer containing $1 \mathrm{nM}$ [ ${ }^{3} \mathrm{H}$ ]YM-09151-2 (83.1 Ci/mmol), $0.5 \mu \mathrm{M}$ DTG ( $\sigma_{1} / \sigma_{2}$ agonist $), 0.1 \mu \mathrm{M}$ pindolol (5-HT $\mathrm{HA}_{1 \mathrm{AB}}$ antagonist) $\mathrm{m}$ and $600 \mathrm{nM} \mathrm{S}(-)$-raclopride to block D2 receptor binding. Nonspecific binding was determined in the presence of $10 \mu \mathrm{M} \mathrm{S}(-)$-sulpiride (D4 antagonist). Sections were subsequently washed in ice-cold preincubation buffer $(2 \times 5 \mathrm{~min})$ followed by a final rinse in ice-cold deionized water.

D2 receptor-stimulated G-protein activation was determined using $\left[{ }^{35} \mathrm{~S}\right] \mathrm{GTP} \gamma \mathrm{S}$ (PerkinElmer) autoradiography following the procedures of Sim et al. (1995) and Blume et al. (2013). Sections were preincubated for $10 \mathrm{~min}$ at room temperature in $50 \mathrm{~mm}$ Tris- $\mathrm{HCl}$ containing $100 \mathrm{~mm}$ $\mathrm{NaCl}, 0.2 \mathrm{~mm}$ EGTA, and $3 \mathrm{~mm} \mathrm{MgCl}_{2}$, pH 7.4, followed by $25 \mathrm{~min}$ in the same buffer containing $1 \mathrm{~mm}$ GDP and $1 \mu \mathrm{M}$ DPCPX $\left(\mathrm{A}_{1}\right.$ adenosine receptor antagonist). D2 receptor-stimulated activity was determined by incubation for $120 \mathrm{~min}$ in the same buffer containing $0.04 \mathrm{nM}\left[{ }^{35} \mathrm{~S}\right] \mathrm{GTP} \gamma \mathrm{S}$ and $3 \mu \mathrm{M}$ of the D2 receptor agonist NPA. Basal activity was determined in the absence of the agonist. Sections were subsequently washed in ice-cold preincubation buffer $(2 \times 5 \mathrm{~min})$ followed by a final rinse in ice-cold deionized water. Sections were then dried overnight in a hood under a stream of cool air and then apposed with $\left[{ }^{3} \mathrm{H}\right]$ standards (American Radiolabeled Chemicals) for $\left[{ }^{3} \mathrm{H}\right]$ raclopride and $\left[{ }^{3} \mathrm{H}\right] \mathrm{YM}-09151-2$ assays or $\left[{ }^{14} \mathrm{C}\right]$ standards (GE Healthcare) for $\left[{ }^{35} \mathrm{~S}\right] \mathrm{GTPyS}$ to Hyperfilm.

Exposure cassettes containing the film with opposed slides were stored in the dark at room temperature. The film was developed after 10 weeks for $\left[{ }^{3} \mathrm{H}\right]$ raclopride, 8 weeks for $\left[{ }^{3} \mathrm{H}\right] \mathrm{YM}-09151-2$, and $24 \mathrm{~h}$ for $\left[{ }^{35} \mathrm{~S}\right] \mathrm{GTPyS}$. Autoradiograms were analyzed by quantitative densitometry using MCID (Imaging Research). Curves from $\left[{ }^{3} \mathrm{H}\right]$ and $\left[{ }^{14} \mathrm{C}\right]$ standards were used for conversion of the optical density values to tissue equivalent values ( $\mathrm{fmol} / \mathrm{mg}$ wet weight tissue). Measurements of total binding were taken from the mPFC of both hemispheres from four serial sections and averaged together into a single measurement for each subject. Specific and D2 receptor-stimulated binding were determined by subtracting nonspecific and basal binding, respectively, from total binding in adjacent sections.

\section{Immunochemistry}

D2 receptor immunoreactivity was determined in the mPFC of control and 1 week withdrawn CIE rats. In brief, rats were transcardially perfused with PBS, $\mathrm{pH} 7.4$, followed by $10 \%$ formalin. The brain was rapidly removed from the skull and immediately immersed in $10 \%$ formalin overnight followed by immersion in 30\% sucrose for $48 \mathrm{~h}$. Brains were subsequently frozen on dry ice and sectioned coronally at $40 \mu \mathrm{m}$ using a sliding microtome. Free floating sections containing the mPFC were then processed for D2 receptor labeling using standard avidin-biotin complex (ABC) methods. Tissue was incubated in D2 receptor primary antibody (rabbit polyclonal, 1:500; Ken Mackie, Indiana University) overnight at room temperature followed by incubation in biotinylated donkey antirabbit secondary antibody (1:1000; Jackson ImmunoResearch) for 30 min. The antigen was visualized by incubation in $\mathrm{ABC}$ (Vectastain Elite Kit; Vector Laboratories) for $60 \mathrm{~min}$ followed by incubation in $0.025 \%$ $3,3^{\prime}$-diaminobenzidine and $0.015 \%$ hydrogen peroxide for $4 \mathrm{~min}$. Following D2 receptor labeling, sections were mounted onto Frost Plus slides, dried, dehydrated, and coverslipped in preparation for analysis. For each rat, D2 receptor-immunoreactive (IR) neurons were counted in four consecutive mPFC sections spaced $200 \mu \mathrm{m}$ apart within a $500 \mu \mathrm{m}^{2}$ grid laid across layers II/III-VI using an Olympus BX40 microscope magnified with a $20 \times$ objective.

\section{Statistical analysis}

The data were analyzed using Prism version 6 (GraphPad software). For analysis of behavioral flexibility, two separate independent samples $t$ tests were used to compare the two groups on the number of trails required to reach criterion and the total number of errors that occurred during the set shift. For the PR experiment, separate independent samples $t$ tests were used to compare the groups on total active lever presses (e.g., breakpoint) and total reinforcements during the session. A $p$ value of 0.05 was considered significant for all statistical tests. For the electrophysiology experiments, the firing rate data were initially analyzed using a withinsubjects design to determine whether the DA receptor agonist significantly altered evoked firing. The firing rate during baseline was compared with the firing rate following the agonist using a two-tailed related-samples $t$ test. For visual presentation of the data, the change in firing rate was normalized to the baseline and converted to percentage change in evoked firing after DA receptor agonist application. A betweensubjects design was then used to test for significant differences in the effectiveness of the agonist in control compared with CIE-exposed rats. When an agonist was only used to test the effects on firing at one time point after CIE exposure, then an independent-measures $t$ test was used to test for significant differences in evoked firing rate. If multiple time points after the last CIE exposure period were examined, then, as with the D2/D4 agonist quinpirole, a two-way ANOVA was used to compare the effect of the agonist in control versus CIE-exposed rats and the effect of withdrawal time ( 1 week vs 4 weeks). Evoked synaptic currents were analyzed using an identical statistical approach. Within-subjects comparisons that reached significance are marked with an asterisk $\left(^{*}\right)$ and significant effects in between-subjects comparisons are marked with a (\#) symbol. A two-tailed, paired, independent samples $t$ test was used to test for differences in the normalized Kv3.1/3.2 current at each holding potential.

\section{Results}

\section{Ethanol exposure paradigm}

In the present study, we investigated the effects of repeated cycles of ethanol exposure and withdrawal on the behavioral and electrophysiological properties of the PFC in a well characterized rat model of chronic alcohol exposure by vapor inhalation. Rats were subjected to 15 consecutive cycles of ethanol exposure by vapor inhalation, with each cycle consisting of $14 \mathrm{~h}$ in the ethanol vapor chamber, followed by $10 \mathrm{~h}$ in their home cage. At the end of each of the $14 \mathrm{~h}$ exposure periods, the level of intoxication of each rat was assessed using a 5-point behavioral intoxication rating scale (Nixon and Crews, 2002). This measure provided immediate and daily information on the level of intoxication and this rating was used to make any necessary adjustments to the concentration of alcohol vapor in the chambers. For our studies, we chose a target intoxication between slight (rating of 2.0) and moderate (rating of 3.0). The intoxication score averaged across all $15 \mathrm{~d}$ and all rats was $2.6 \pm 0.04$ with an average daily median of $2.5 \pm 0.04$ (Quartiles: $\mathrm{Q} 1=1.9 ; \mathrm{Q} 2=2.5 ; \mathrm{Q} 3=3.4)$. To assess the BEC associated with this level of intoxication, we obtained tail vein blood at the end of vapor exposure on days 2, 6, 10, and 15. This revealed average BEC values (in $\mathrm{mg} \%$ ) of $256.5 \pm 19.6,287.5 \pm 16.4$, $253.0 \pm 20.9$, and $321.2 \pm 18.1$, respectively, and an overall grand average across all $4 \mathrm{~d}$ of $279.7 \pm 9.4 \mathrm{mg} \%$.

\section{Behavioral assessment}

To assess whether this model of CIE exposure altered the cognitive function of the mPFC, we used an operant set-shifting task that assesses the ability of the rat to flexibly alter its behavior in response to a rule change. Importantly, optimal performance on this task has been shown to be mPFC dependent and is modulated by DA receptor signaling in the $\mathrm{MPFC}$ and nucleus accumbens (Floresco et al., 2008; Haluk and Floresco, 2009). Before exposure to CIE, the rats underwent an initial training period on the operant procedure in which they learned to lever press for the reward guided by a visual cue of a light presented above the correct lever (Fig. 1A, left). Rats in both groups acquired this discrimination at a comparable rate $\left(F_{(1,14)}=1.071, p=0.3182\right.$, 
n.s.). After training to criteria, they were then subjected to CIE exposure and then returned to their home cage and allowed to withdraw for a period of 1 week, after which they were given another visual-cue discrimination session. Again, there were no difference in rats that received CIE $(n=7)$ versus the control group $(n=9$; $F_{(1,14)}=0.3765$, n.s., $p=0.5493$; Fig. $1 A$, right), indicating that CIE did not impair retrieval of the previously acquired visualcue rule.

On the following day, rats were tested for their ability to shift respond from the visual-cue rule to the location rule (i.e., left or right lever). As shown in Figure $1 B$, rats that had been exposed to $\mathrm{CIE}(n=7)$ required significantly more trials to shift their response from the visual-cue rule to the position rule compared with controls ( $n=9$; unpaired $t$ test, $t_{(14)}=2.204, p=$ 0.0224). As expected, this was associated with a significant increase in the number of response errors (Control: $15.67 \pm 1.46$; CIE: $25.71 \pm 2.99 ; t_{(14)}=3.236, p=$ 0.0030; Fig. 1C). This suggests that the CIE-exposed rats had greater difficulty relative to control rats with updating their strategy in response to the change in reward contingency.

To determine whether CIE altered the rats motivation to obtain the reward, we measured instrumental responding for reward on a PR schedule in a separate cohort of rats before and after either control or CIE exposure (Richardson and Roberts, 1996). As shown in Figure $1 D$, there were no differences in lever presses between control and CIE-exposed rats on the active lever $\left(t_{(7)}=0.223, p=0.9827\right.$, paired $t$ test, two tailed, $n=8)$, inactive lever $\left(t_{(7)}=1.392, p=0.2067\right.$, paired $t$ test, two tailed, $n=8)$, or in the break points $\left(t_{(7)}=0.001, p=0.9999\right.$, paired $t$ test, two tailed, $n=8$; data not shown). These data suggest that CIE did not alter reward motivation. Together, these observations are consistent with clinical observations of deficits in executive function in the abstinent alcoholic.

\section{Electrophysiological studies}

The set-shifting task we conducted is critically dependent on intact dopaminergic function in the mPFC (Floresco et al., 2008). We therefore hypothesized these deficits in cognitive ability may be associated with alterations in dopaminergic modulation of neurotransmission in this region. To investigate this at the cellular level, we performed whole-cell patch-clamp recordings in acute brain slices containing the MPFC from control and CIEexposed rats.

As has been previously reported, bath application of the D1 receptor agonist SKF38393 $(5 \mu \mathrm{M})$ to slices obtained from control rats significantly increased firing evoked by intracellular current injection in Layer V PrL-mPFC pyramidal neurons $\left(t_{(7)}=5.290\right.$, $p=0.0011$; Fig. $2 A, D)$, whereas application of the $\mathrm{D} 2$ receptor agonist quinpirole $(5 \mu \mathrm{m})$ significantly reduced evoked firing $\left(t_{(7)}=6.204, p=0.0251\right.$; Fig. $\left.2 B, D\right)$. The inhibitory effect of quinpirole was specifically mediated by D2 receptors since coapplication of the D2 receptor antagonist sulpiride completely blocked the effect of quinpirole $\left(102.5 \pm 6.3 \%\right.$ of baseline; $t_{(7)}=$
B

Shift to Location Rule

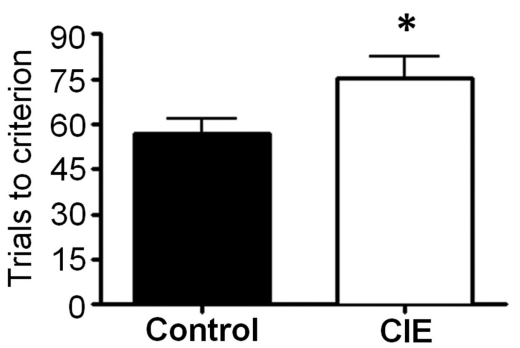

Progressive Ratio

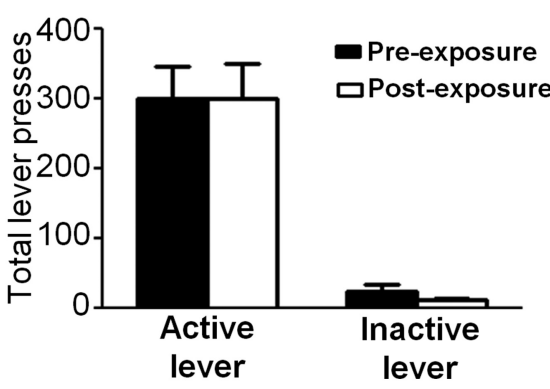

Figure 1. CIE exposure resulted in deficits in performance on an operant set-shifting task. Rats were tested 1 week after the last dis of ethanol exposure. $\boldsymbol{A}$, Control and CIE animals performed the visual-cue discrimination equally well both before and after increase in the number of response errors. $n=9$ controls and $n=7$ CIE rats. $D$, Control and CIE-exposed rats showed equal reward motivation when tested on a PR responding procedure. ${ }^{*} p<0.05$ for all comparisons, $n=8$ controls and $n=8$ CIE rats.

$0.2098, p=0.8398$; data not shown). In contrast, bath application of the D4 receptor agonist PD168077 (40 $\mu \mathrm{M})$ had no effect $\left(t_{(7)}=0.8221, p=0.4381\right)$ on evoked firing of pyramidal neurons (Fig. 2C,D).

We next examined the effects of DA receptor stimulation on evoked firing of pyramidal cells in slices obtained from CIEexposed rats. While the stimulatory effect of $\mathrm{D} 1$ receptor activation on evoked firing was not affected by CIE exposure (119.31 $4.65 \%$ increase above baseline; $t_{(7)}=5.991, p=0.0005$; Fig. $2 A, D)$, there was a complete loss of inhibition of firing by D2 receptor stimulation following CIE exposure $(98.17 \pm 3.29 \%$ of baseline, $t_{(7)}=0.1876, p=0.8565$; Fig. $2 B, D$ ). Similar to control slices, D4 receptor stimulation in CIE-exposed slices also had no effect on firing $\left(t_{(7)}=1.335, p=0.2235\right.$; Fig. $\left.2 C, D\right)$. However, these changes in DA modulation of evoked firing by CIE were not accompanied by alterations in other intrinsic properties of pyramidal neurons, including evoked firing frequency $(5.1 \pm 0.6 \mathrm{~Hz}$, control; $4.9 \pm 0.4 \mathrm{~Hz}, \mathrm{CIE})$, threshold $(-37.7 \pm 9.1 \mathrm{mV}$, control; $-39.8 \pm 7.2 \mathrm{mV}, \mathrm{CIE})$, action potential duration $(3.6 \pm 0.3 \mathrm{~ms}$, control; $3.4 \pm 0.2 \mathrm{~ms}$, CIE), action potential amplitude (82.6 \pm $9.5 \mathrm{mV}$, control; $79.9 \pm 4.7 \mathrm{mV}$, CIE), and membrane resting potential ( $-61.7 \pm 4.6 \mathrm{mV}$, control; $-60.2 \pm 5.3 \mathrm{mV}, \mathrm{CIE})$.

To examine whether withdrawal was required to produce the loss of D2 receptor function, we also obtained slices from rats immediately following CIE exposure and found no effect of D2 receptor stimulation on firing $(97.08 \pm 6.4 \%$ of baseline; $n=5$, $\left.t_{(5)}=0.2285, p=0.8282\right)$. To determine the persistence of the loss of D2 modulation, we also recorded in slices from rats at 4 weeks following CIE exposure and found that D2 receptor function remained absent $\left(92.82 \pm 4.84 \%\right.$ of baseline, $t_{(7)}=1.646$, $p=0.1437$; Fig. $2 E$ ). Additionally, two-way ANOVA analysis revealed a main effect of CIE exposure $\left(F_{(1,27)}=14.90, p=\right.$ 

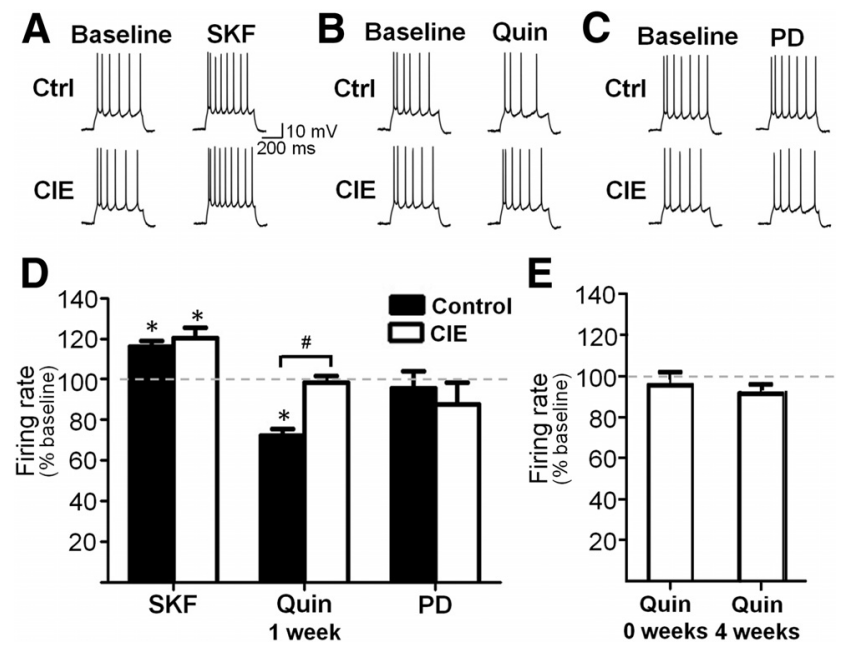

E

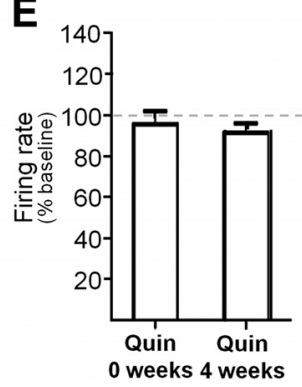

Figure 2. D2 and D4 receptor modulation of evoked firing of pyramidal neurons was absent following CIE exposure. A, D, Bath application of the D1 receptor agonist SKF38393 (SKF) increased evoked firing in pyramidal neurons from control and CIE rats 1 week after the last day of exposure. $\boldsymbol{B}, \boldsymbol{D}, \mathbf{D} 2$ receptor stimulation with quinpirole (Quin) decreased firing in control slices, but this effect is abolished in slices from CIE rats following 1 week of withdrawal. C, D, Bath application of a D4 receptor agonist (PD168077; PD) had little effect on firing rate and this was not changed by CIE. E, Quinpirole had no effect in slices obtained immediately following the last day of CIE exposure and this effect persisted in slices from rats following 4 weeks of withdrawal from CIE. ${ }^{*} p<0.05$ versus baseline, $\# p<0.05$ control versus $\mathrm{CIE}, n=7-8$ cells from 4 to 5 rats/group.

$0.0006)$ but no effect of withdrawal time $\left(F_{(1,27)}=0.91, p=\right.$ 0.3484 ), suggesting that the loss of D2 receptor function was persistent and unrelated to the process of withdrawal.

The above observations clearly demonstrate that CIE exposure resulted in the loss of D2 receptor modulation of evoked firing of pyramidal neurons in slices from the mPFC. However, the mechanisms by which D2 and D4 receptors modulate firing are likely distinct from the mechanism(s) by which they modulate synaptic transmission. Therefore, in the next set of experiments we examined the effect of D2 and D4 receptor stimulation of evoked glutamatergic and GABAergic synaptic currents recorded from pyramidal neurons. As shown in Figure $3 A$, no differences in the amplitude of baseline eIPSCs were observed between control and CIE-exposed rats at $1\left(t_{(7)}=0.5831, p=\right.$ $0.5781)$ and 4 weeks of withdrawal $\left(t_{(10)}=0.1088, p=0.9155\right)$. As has been reported previously, bath application of either a D2 or D4 receptor agonist significantly reduced the amplitude of eIPSC in slices obtained from control rats (quinpirole: $72.1 \pm$ 3.4\% of baseline, $t_{(4)}=5.894, p=0.0041$; PD168077: $70.4 \pm$ $5.9 \%$ of baseline, $t_{(4)}=5.455, p=0.0055$; Fig. $\left.3 B, C\right)$. Coapplication of the receptor agonists with the D2 receptor antagonist sulpiride or the D4 receptor antagonist L745870 prevented the inhibitory effects of receptor activation $(98.6 \pm 5.2 \%$ of baseline, $t_{(4)}=0.1204, p=0.9100$ for quinpirole and $101.2 \pm 4.2 \%$ of baseline, $t_{(4)}=0.2167, p=0.8390$ for PD168077). Similar to the loss of the effect on evoked firing, CIE exposure induced a complete loss of the inhibitory effect of both D2 $\left(F_{(1,17)}=24.23, p=\right.$ 0.0001 control vs CIE at 1 week; no effect of withdrawal length $\left.F_{(1,17)}=0.81, p=0.3813\right)$ and $\mathrm{D} 4\left(t_{(3)}=0.6258, p=0.5758\right.$, control vs CIE at 1 week withdrawal) receptor activation on eIPSC amplitude.

Examination of sIPSCs (data not shown) revealed that CIE treatment had no effect on the amplitude $\left(F_{(1,10)}=0.89, p=\right.$ $0.3679, n=6)$ or frequency $\left(F_{(1,10)}=0.00, p=0.9766, n=6\right)$ of sIPSCs. However, there was a significant interaction between the effect of quinpirole and CIE treatment such that quinpirole decreased sIPSC amplitude in controls $(71.7 \pm 4.7 \%$ of baseline) but had no effect on sIPSC amplitude in CIE-exposed rats $\left(98.6 \pm 5.4 \%\right.$ of baseline; $\left.F_{(1,10)}=39.5, p<0.0001\right)$. In contrast, there was no effect of quinpirole on the frequency of sIPSCs in either control (100.7 $\pm 2.9 \%$ of baseline) or CIE-exposed rats $\left(97.7 \pm 2.4 \%\right.$ change from baseline; $F_{(1,10)}=0.10, p=0.7539$, $n=6$ ), further indicating there was no presynaptic effect of CIE on GABA release. Similar results were obtained with D4 receptor agonist as no changes in the amplitude $\left(F_{(1,10)}=1.54, p=0.2426\right.$, $n=6)$ or frequency $\left(F_{(1,10)}=0.20, p=0.6648, n=6\right)$ of sIPSCs between control and CIE-exposed rats were observed. There was an interaction between the effect of PD168077 and CIE treatment such that bath application decreased sIPSC amplitude in controls but had no effect on sIPSC amplitude in CIE-treated rats $\left(F_{(1,10)}=25.45, p=0.0005\right)$. As with quinpirole, PD168077 had no effect on the frequency of sIPSCs in either control or CIE-treated rats $\left(F_{(1,10)}=1.34, p=0.2739, n=6\right)$. These data further support our findings that CIE exposure does not result in altered GABAergic function at 1 week or 4 weeks of withdrawal. However, consistent with our observations of evoked synaptic responses and firing, D2 receptor modulation of spontaneous GABA currents is also impaired for an extended period of time following CIE exposure.

In addition to inhibition of $\mathrm{GABA}_{\mathrm{A}}$ receptor currents, $\mathrm{D} 2$ and D4 receptors have also been reported to reduce the amplitude of NMDA currents (Wang et al., 2003; Beazely et al., 2006). We therefore examined the effects of CIE exposure on modulation by D2 and D4 receptor stimulation of eNMDA currents. In contrast to the lack of effect of CIE exposure on the baseline amplitude of eIPSCs, CIE exposure increased the baseline amplitude of eNMDA currents when examined after either 1 week $\left(t_{(6)}=\right.$ $3.112, p<0.0208)$ or 4 weeks of withdrawal $\left(t_{(10)}=5.635, p=\right.$ $0.0002)$. There was no significant effect of withdrawal time on the magnitude of that increase $\left(F_{(1,16)}=1.17, p=0.2947\right.$; Fig. $\left.4 A\right)$. Consistent with a recent report in a mouse model of CIE exposure by vapor inhalation (Kroener et al., 2012), this increase in eNMDA current amplitude after 1 week of withdrawal from CIE did not appear to be not associated with an increase in expression of NMDA receptors (GluN1: $t_{(12)}=1.629, p=0.1293$; GluN2A: $t_{(13)}=0.2171, p=0.8315$; GluN2B: $t_{(13)}=1.035, p=0.3196 ; n=$ 7-8 per group; Figure $4 B$ ). The reason for the discrepancy between a lack of change in NMDA receptor expression yet an increase in current is not clear, but may relate to circuit specific changes that are not detected when analyzing tissue obtained by punches, which contains diverse neuronal types and synaptic sites of excitatory afferent projections from numerous brain regions. Also in agreement with previous studies, bath application of either quinpirole $\left(t_{(3)}=6.447, p=0.0076\right.$; Fig. $4 C$ ) or $\operatorname{PD} 168077\left(t_{(3)}=4.237 ; p=0.0481\right.$; Fig. $\left.4 D\right)$ significantly reduced the amplitude of eNMDA currents in control slices, an effect that was blocked by application of D2 or D4 receptor antagonists (quinpirole + sulpiride, $p=0.3950$; PD168077 + LY745870, $p=0.7414)$. However, this inhibitory effect was again absent in slices obtained from CIE-exposed rats at 1 week (quinpirole, $p=0.8313$; PD168077, $p=0.6336$ ) and 4 weeks after the last day of ethanol exposure (quinpirole 1 week vs 4 weeks, $\left.F_{(1,16)}=3.05, p=0.0561\right)$; Figure $\left.4 C, D\right)$. We also measured evoked AMPA currents and found no differences between the groups during baseline or following D2 and D4 stimulation (data not shown).

Analysis of sEPSCs (data not shown) indicated there was no difference in the amplitude $\left(t_{(4)}=0.3602, p=0.7369\right)$ or fre- 
A

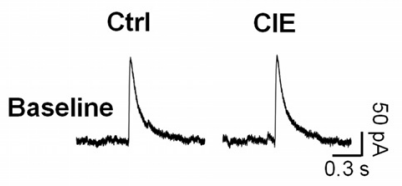

B

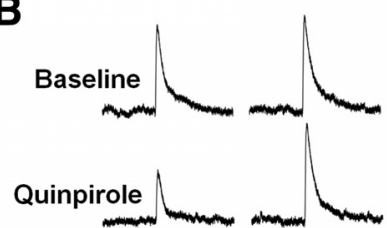

C

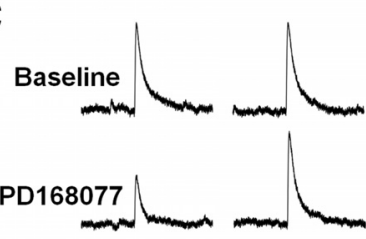

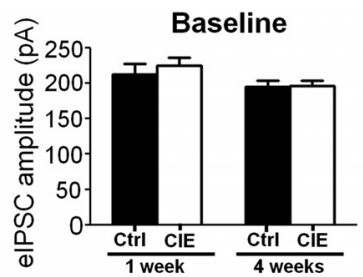

Quinpirole

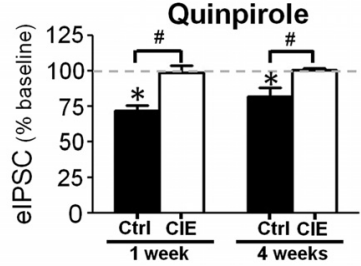

PD168077

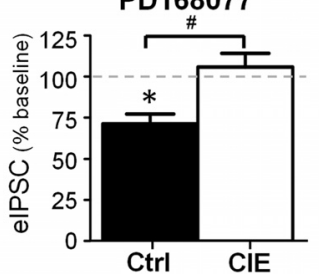

Figure 3. CIE exposure disrupted D2/D4 receptor modulation of evoked IPSCs in prefrontal pyramidal neurons. $\boldsymbol{A}$, CIE did not affect baseline amplitude of eIPSCS. B, Bath application of the $D 2$ receptor agonist quinpirole decreased eIPSC amplitude in control rats but had no effect in slices from CIE animals when recordings were performed at 1 and 4 weeks following CIE exposure. C, The D4 receptor agonist PD168077 decreased eIPSC amplitude in control rats but had no effect in slices from CIE rats. ${ }^{*} p<0.05$ versus baseline, $\# p<0.05$ control versus CIE; $n=4-5$ cells from 4 to 5 rats/group.

quency $\left(t_{(4)}=0.1622, p=0.8790\right)$ of sEPSCs between control and CIE-exposed rats after 1 week of withdrawal. Quinpirole significantly decreased sEPSC amplitude in controls $63.5 \pm$ $2.4 \%$ of baseline) but had no effect on sEPSC amplitude in CIEexposed rats $\left(105.3 \pm 4.4 \%\right.$ of baseline; $F_{(1,4)}=42.04, p<$ $0.0029)$. There was also no effect of quinpirole on the frequency of sEPSCs in either control (104.0 $\pm 5.3 \%$ of baseline) or CIEtreated rats $\left(95.3+5.8 \%\right.$ change from baseline; $F_{(1,4)}=0.25, p=$ $0.6433)$. The D4 agonist PD168077 significantly decreased sEPSC amplitude in controls $\left(70.4 \pm 3.3 \%\right.$ of baseline; $F_{(1,4)}=144.56$, $p=0.0003$ ) but had no effect on sEPSC amplitude in the CIEexposed rats $\left(99.8 \pm 6.2 ; F_{(1,4)}=0.01, p=0.9120\right)$. Finally, there was no effect of PD168077 on the frequency of sEPSCs in either control $(107.6 \pm 6.5)$ or CIE-exposed rats $(102.2 \pm 6.5 \%$ of baseline; $\left.F_{(1,4)}=0.24, p=0.6520, n=4\right)$. These observations further support results obtained with eNMDA currents and suggest that CIE exposure persistently enhances NMDA currents. The enhancement of NMDA currents likely occurs via a postsynaptic modification rather than an increase in glutamate release since we observed an increase in sEPSC amplitude but no change in frequency. Furthermore, these data are consistent with our observations of long-lasting impairment of D2 receptor modulation of eNMDA currents, GABA currents, and evoked firing following CIE.

The above observations strongly suggest that CIE exposure is associated with a loss of D2 and D4 receptor modulation of firing and postsynaptic responses of layer $\mathrm{V}$ pyramidal neurons in the mPFC. One potential mechanism for loss of D2/D4 modulation could be to an uncoupling of the receptors from their intracellular signaling pathways. In addition, this loss of modulation could reflect downregulation of receptor expression. To examine this

A Ctrl CIE B
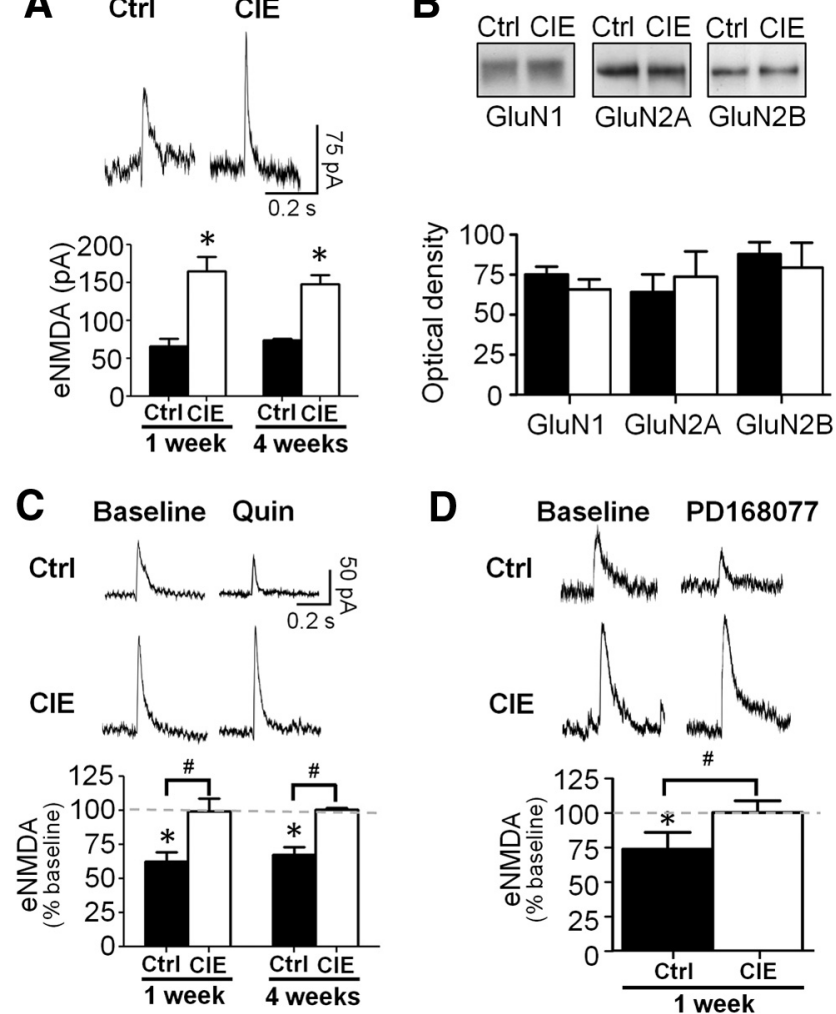

Figure 4. CIE exposure increased NMDA currents and attenuated D2/D4 receptor modulation of NMDA function in pyramidal neurons of mPFC. $A$, Slices obtained after 1 and 4 weeks of withdrawal from CIE rats showed significantly larger eNMDA currents compared with controls at 1 and 4 weeks following exposure. ${ }^{*} p<0.05$ versus control, $n=5-6$ cells from four rats. $\boldsymbol{B}$, Expression of NMDA receptor subunits was not affected by CIE. $\boldsymbol{C}$, Bath application of the D2 receptor agonist quinpirole reduced eNMDA amplitude in control rats but had no effect in slices from CIE-exposed rats and this effect persisted at both 1 and 4 weeks of withdrawal. D, The D4 receptor agonist PD168077 reduced eNMDA amplitude in controls but had no effect in CIEtreated animals when tested 1 week following exposure. ${ }^{*} p<0.05$ versus baseline, $n=4-6$ cells from 4 rats.

latter possibility, we attempted to measure the levels of $\mathrm{D} 2$ receptors in tissue punches of the mPFC obtained from control and CIE-exposed rats after 1 week of withdrawal using standard immunoblotting procedures. For these studies, we tested five different D2 receptor antibodies. All antibodies recognized a prominent band at $-70 \mathrm{kDa}$ and a lower band of $40-50 \mathrm{kDa}$ whose exact size varied depending upon the particular antibody. However, when we examined the specificity of the antibodies using $\mathrm{MPFC}$ and striatal tissue obtained from wild-type and D2 receptor knock-out mice (strain $\mathrm{B} 6.129 \mathrm{~S} 2-D r d 2^{\text {tm1Low }} / \mathrm{J}$ ), we found no difference in the intensity of any of the bands for any of the $\mathrm{D} 2$ receptor antibodies tested. This observation raised serious concerns about the ability to accurately quantify D2 receptor expression in brain tissue extracts using immunoblotting procedures.

As an alternative approach to immunoblotting, we next used quantitative in vitro receptor autoradiography to measure D2 and $\mathrm{D} 4$ receptor density in the $\mathrm{mPFC}$. These studies revealed no differences in either D2 or D4 binding in the MPFC between control and 1 week withdrawn CIE-exposed rats (Fig. $5 B$ ). In addition to examination of specific binding of D2 receptors to measure receptor density, we also examined the effects of CIE exposure on D2 receptor-G-protein coupling using D2 receptor-stimulated $\left[{ }^{35} \mathrm{~S}\right] \mathrm{GTP} \gamma \mathrm{S}$ autoradiography. This revealed that CIE exposure 
A

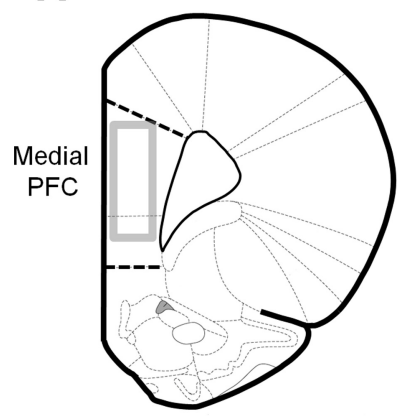

B
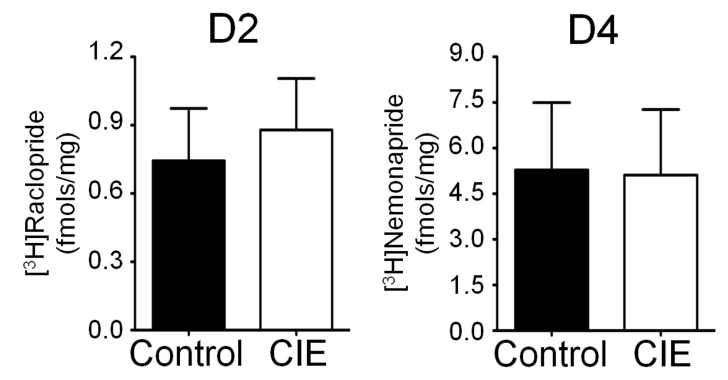

C

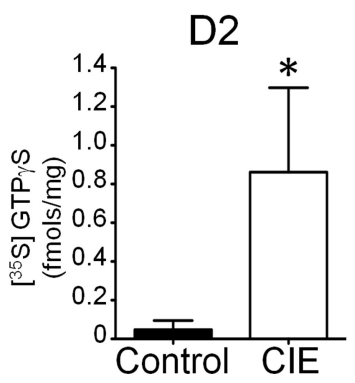

D

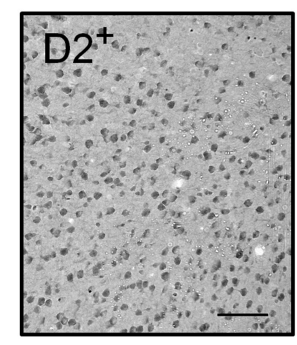

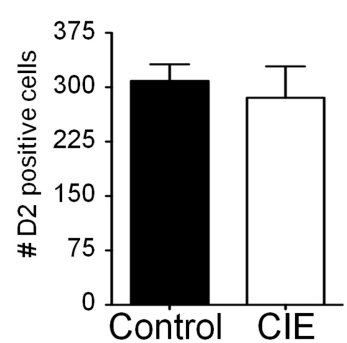

Figure 5. CIE does not alter D2/D4 receptor expression in the mPFC. $A$, Coronal view of the rat brain atlas of the mPFC showing the region (gray box) of analysis of D2/D4 receptor expression. $B$, Quantitative autoradiography of D2 receptor binding using $\left[{ }^{3} \mathrm{H}\right.$ ]raclopride (left graph) and D4 receptor binding with [ $\left.{ }^{3} \mathrm{H}\right]$ nemonapride (right graph) demonstrating no difference in specific binding between control and CIE-exposed rats ( 1 week withdrawal; $n=8$ /group; $p=0.60$, unpaired $t$ test). $C$, CIE exposure was associated with an increase in D2 receptor-stimulated [ $\left.{ }^{35} \mathrm{~S}\right] \mathrm{GTP} \gamma$ S binding (CIE: $n=7$; control: $n=6 ;{ }^{*} p<0.02$, unpaired $t$ test). $D$, CIE exposure did not alter the number of $D 2$ receptor-IR-positive cells in the $\mathrm{mPFC}(n=6 /$ group; $p=0.27$, unpaired $t$ test). Scale bar, $100 \mu \mathrm{m}$.

was associated with a significant increase in incorporation of $\left[{ }^{35} \mathrm{~S}\right] \mathrm{GTP} \gamma \mathrm{S}$ in the mPFC (Fig. $5 D$ ). In light of the electrophysiology studies demonstrating a loss of D2 receptor modulation of intrinsic and synaptic activity, together with no change in receptor density as indicated by the autoradiographical binding studies, this increase in D2 receptor-stimulated $\left[{ }^{35} \mathrm{~S}\right] \mathrm{GTP} \gamma \mathrm{S}$ is consistent with a compensatory increase in D2 receptor G-protein coupling, potentially in response to a functional uncoupling of receptor G-protein activation from downstream signaling pathways.

One caveat to the autoradiographical analysis of D2/D4 receptors in the PFC is the low level of specific binding that is typically observed in this region. Therefore, as a complementary approach, we next used quantitative immunohistochemistry (IHC) to examine the density of D2 receptors in the mPFC. Since the specificity of the Mackie D2 receptor antibody has been confirmed for use in IHC by immunostaining fixed slices obtained from wild-type versus D2 knock-out mice (Garzón et al., 2013), we used that antibody to examine the effect of CIE exposure on D2 receptor expression in the $\mathrm{mPFC}$. Consistent with the results from the receptor autoradiography studies, analysis of D2 receptor immunoreactivity in the mPFC revealed no differences between control and CIE exposure (Fig. 5D). Together, these observations suggest that the loss of D2/D4 receptor modulation of neurotransmission following CIE exposure is not associated with a reduction in the expression of these receptors.

In the next set of electrophysiology experiments, we expanded our investigation to include cortical interneurons. We focused these studies on FS interneurons as they are known to exert powerful effects over pyramidal cell output and are the primary subtype of interneuron affected by DA in the PFC (Lewis et al., 1998). In addition, the modulatory action of DA on FS interneuron activity is thought to be critical for the generation of network activity that underlies cognitive function. Consistent with previous observations (Trantham-Davidson et al., 2008), bath application of the D1 receptor agonist SKF38393 enhanced evoked firing of FS interneurons in control slices, and this effect was not altered by CIE exposure (Control: $t_{(7)}=3.171, p=0.0157$; Fig. $6 A, B)$. In contrast to the inhibitory action of D2 receptor stimulation on evoked firing of pyramidal neurons, bath application of quinpirole enhanced the firing rate of FS interneurons $t_{(7)}=$ 4.150, $p=0.0043)$. This is consistent with a previous report demonstrating that the stimulatory effect of D2 receptors on FS interneurons is developmentally regulated and emerges in the adult at the end of adolescence (Tseng and O'Donnell, 2007). Similarly, bath application of the D4 agonist PD168077 also had a powerful stimulatory effect of evoked firing of FS interneurons $\left(t_{(7)}=\right.$ 4.144, $p=0.0043$ ). However, in slices obtained from CIE-exposed rats, there was again a complete loss of the effect of quinpirole ( 1 week after CIE: $t_{(7)}=$ $0.1263, p=0.9031$; 4 weeks after CIE: $\left.t_{(3)}=0.3828, p=0.7274\right)$ and PD168077 ( 1 week after CIE: $t_{(7)}$ $=1.193, p=0.2717$ ) on evoked firing of FS interneurons (Fig. $6 A, B)$. This indicates that the effect of CIE exposure on D2 and D4 receptor modulation of neurotransmission in the mPFC was broad based and not cell-type specific.

We next compared intrinsic properties and evoked firing rates of the neurons during baseline recordings and found no differences between control and CIE on any of the properties of FS interneurons with the exception of the effects of D4 receptor modulation. In slices from control rats, the D4 receptor enhancement of firing was associated with a reduction in action potential (AP) duration $\left(t_{(14)}=4.796, p=0.0003\right.$; Fig. $\left.6 C\right)$. As expected, this reduction in AP duration was absent in slices from CIEexposed rats.

The AP duration of FS interneurons is known be mediated in part by Kv3.1/3.2 channels, as genetic knock-out of this channel results in a loss of the FS phenotype of these cells (Chow et al., 1999; Erisir et al., 1999; Rudy et al., 1999; Goldberg et al., 2005;Goldberg et al., 2011). The reduction in AP duration in response to application of PD168077 is consistent with enhancement of Kv3.1/3.2-mediated currents. Therefore, we next examined the effects of D4 receptor stimulation on the Kv3.1/3.2 current. As expected, D4 receptor stimulation enhanced the Kv3.1/3.2 current resulting in faster repolarization, shorter AP duration, and increased evoked firing rate in slices obtained from control rats $\left(t_{(4)}=4.012, p=0.0042\right.$ at step voltage of $+20 \mathrm{mV}$; Fig. $6 \mathrm{D}$ ). Also as expected, the effect of D4 receptor stimulation was absent in slices from CIE-exposed rats. To confirm the selectivity of PD168077 for D4 receptor modulation of Kv3.1/3.2, we coapplied PD168077 with the D4 receptor antagonist 
L745870 and found that D4 receptor inhibition of AP duration was no longer observed (data not shown).

Given the critical role of FS interneurons in controlling cortical networks, we next examined an alternative mechanism for modulating FS interneuron activity that may not be affected by CIE exposure. Of interest was the recent report that mGluR1 receptors in the $\mathrm{mPFC}$ have a primary site of action on FS interneurons (Sun and Neugebauer, 2011). In agreement with this, we observed that bath application of the mGluR1-positive allosteric modulator Ro67-7476 and Ro411401 to slices obtained from control rats increased evoked firing of FS interneurons $\left(t_{(3)}=3.236, p=0.0027\right.$; Fig. $\left.7 A\right)$, decreased spike duration $\left(t_{(3)}=5.180\right.$, $p=0.0017$; Fig. 7B), and increased Kv3.1/ 3.2 currents $\left(t_{(3)}=2.047, p=0.0051\right.$ at step voltage of $+20 \mathrm{mV}$; Fig. $7 C$ ). However, in contrast to the CIE-induced loss of D2 and D4 receptor modulation of firing, CIE exposure had no effect upon any parameters of mGluR1 modulation of FS interneuron activity. In a separate set of experiments, we also recorded from pyramidal neurons and observed that bath application of Ro67-7476 significantly reduced evoked firing $\left(t_{(3)}=4.988, p=\right.$ 0.0117; Fig. 7D). However, coapplication of Ro67-7476 with picrotoxin to block $\mathrm{GABA}_{\mathrm{A}}$ receptors completely prevented the effect of Ro67-7476, suggesting that the mGluR1 inhibition of pyramidal cell firing was not a direct action on the pyramidal neuron but was an indirect effect of enhanced firing of FS interneurons.

\section{Discussion}

In the present study, we used a rat model of CIE exposure to examine ethanolinduced changes in cognitive function and neurotransmission in the PFC. Consistent with similar observations in abstinent alcoholics, we observed deficits in behavioral flexibility on a strategy setshifting task when assessed 1 week after the last day of alcohol exposure. Using patch-clamp slice electrophysiology to record from layer $\mathrm{V}$ pyramidal and FS interneurons in the MPFC, we demonstrate that CIE exposure abolished D2 and D4 receptor modulation of evoked firing and synaptic transmission without altering either D1 receptor or mGluR1 modulation of neurotransmission. The loss of DA receptor modulation was also observed when measured in slices obtained immediately after CIE exposure (i.e., no withdrawal), and this loss was still observed in slices obtained from rats 4 weeks after CIE exposure. Furthermore, this loss of modulatory activity did not appear to be due to a change in receptor expression. Together, these observations suggest that chronic ethanol-induced deficits in executive function may relate to

D
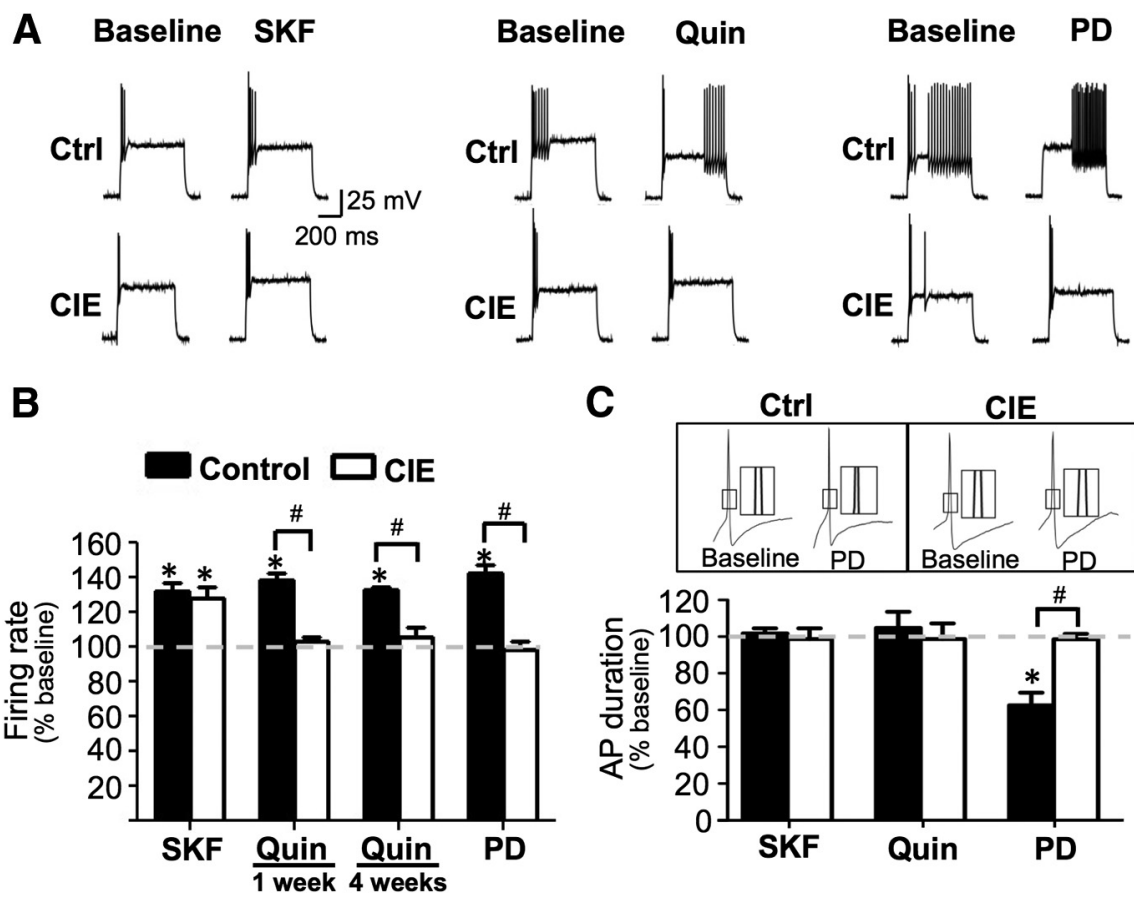

C Ctrl
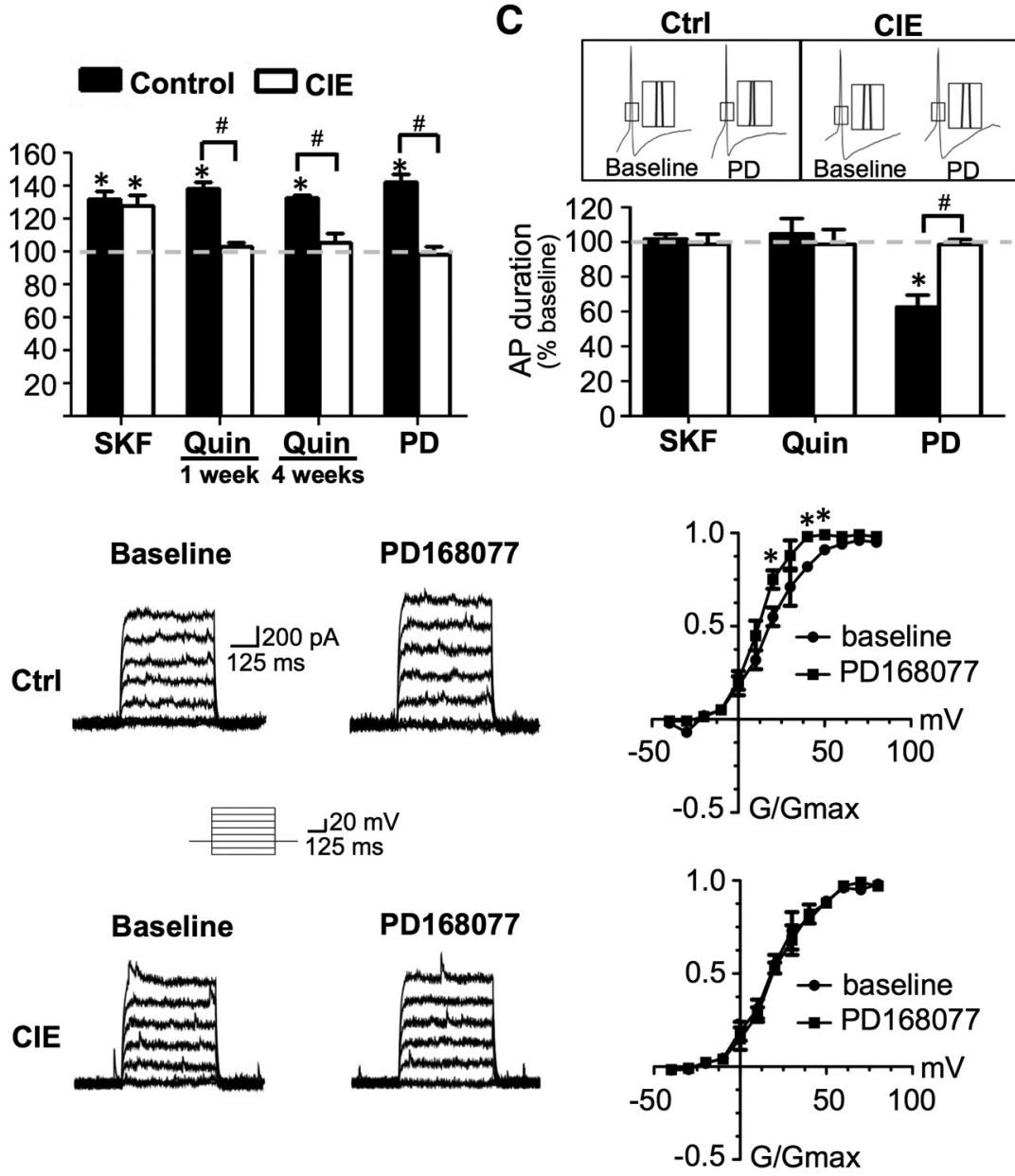

Figure 6. D2/D4 receptor modulation of evoked firing in $\mathrm{FS}$ interneurons was attenuated in CIE-exposed rats. $A, B$, Bath application of a D1 receptor agonist increased evoked firing in both controls and CIE rats. In contrast, bath application of either a D2 or D4 agonist increased firing in control animals, but this effect was absent in slices from CIE animals at 1 and 4 weeks of withdrawal from CIE exposure. C, The increased firing rate observed following D1 and D2 receptor stimulation in controls did not occur via changes in spike duration and this was not affected by CIE. However, the increase in firing observed with D4 receptor stimulation occurred at least in part due to a reduction in action potential duration and this effect was absent in CIE rats. ${ }^{*} p<0.05$ versus baseline, paired $t$ test, $n=4-7$ cells from 4 to 6 rats. D, Kv3.1/3.2 currents were enhanced by bath application of a D4 receptor agonist in control slices (top) but were not affected by D4 receptor stimulation in CIE slices (bottom). ${ }^{*} p<0.05$ versus baseline, paired $t$ test, $n=4-5$ cells from four rats. Quin, quinpirole, PD, PD168077; SKF, SKF38393.

disruption of D2/D4 receptor modulation of the neural networks of the PFC that underlie cognition.

Increasing evidence indicates that the proper functioning of the PFC plays a critical role in exerting inhibitory control over impulsive behaviors that characterize drug and alcohol addiction. Abstinent alcoholics who exhibit deficits in executive function have a greater probability of relapse (Wicks et al., 2001; Charney et al., 2010), and therapeutic enhancement of cognitive functioning in the abstinent alcoholic may reduce the incidence of relapse (Schacht et al., 2011). However, while alcoholism has 

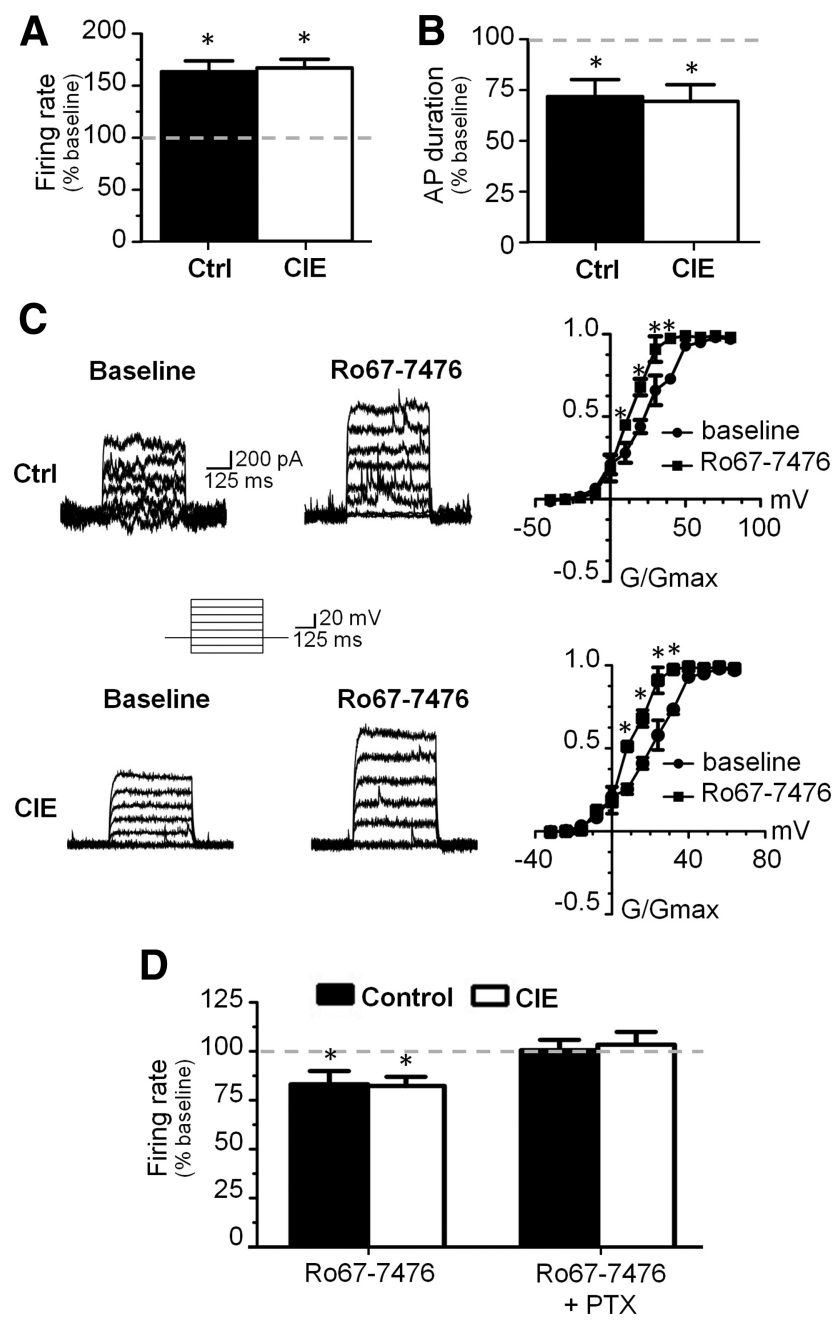

Figure 7. mGluR1 stimulation selectively enhanced FS interneuron firing. A, Bath application of mGluR1 PAM Ro67-7476 increased evoked firing in FS interneurons of both control and CIE slices. B, Bath application of mGluR1 PAM Ro67-7476 decreased action potential duration in both controls and CIEs. C, mGluR1 PAMs Ro67-7476 and Ro71-1401 increased Kv3.1/3.2 currents in both control and CIE slices. D, Bath application of mGluR1 PAM decreased evoked firing of pyramidal neurons in both control and CIE slices and this effect was blocked by the $\mathrm{GABA}_{\mathrm{A}}$ blocker picrotoxin (PTX). ${ }^{*} p<0.05$ versus baseline, paired $t$ test, $n=4$ cells from four rats.

been associated with deficits in executive function that often persist well into abstinence, the structural and functional changes in the brain that underlie these deficits are largely unknown. In addition, clinical studies investigating the impact of chronic alcohol consumption on cognition are confounded by the potential that the cognitive deficits may represent a pre-existing condition and are not the result of chronic alcohol consumption. Therefore, rodent models of alcohol dependence are extremely useful as they allow for investigation at the cellular and molecular level, but also allow for control of confounding factors such as pre-existing cognitive status. The CIE-exposure model used in the current study is a particularly useful procedure because it models the effects of repeated episodes of intoxication and withdrawal associated with high levels of blood alcohol that generally cannot be achieved in rodents by voluntary ethanol consumption. Our observation that CIE exposure by vapor inhalation results in deficits in behavioral flexibility suggests that chronic alcohol exposure directly impairs the cognitive function of the
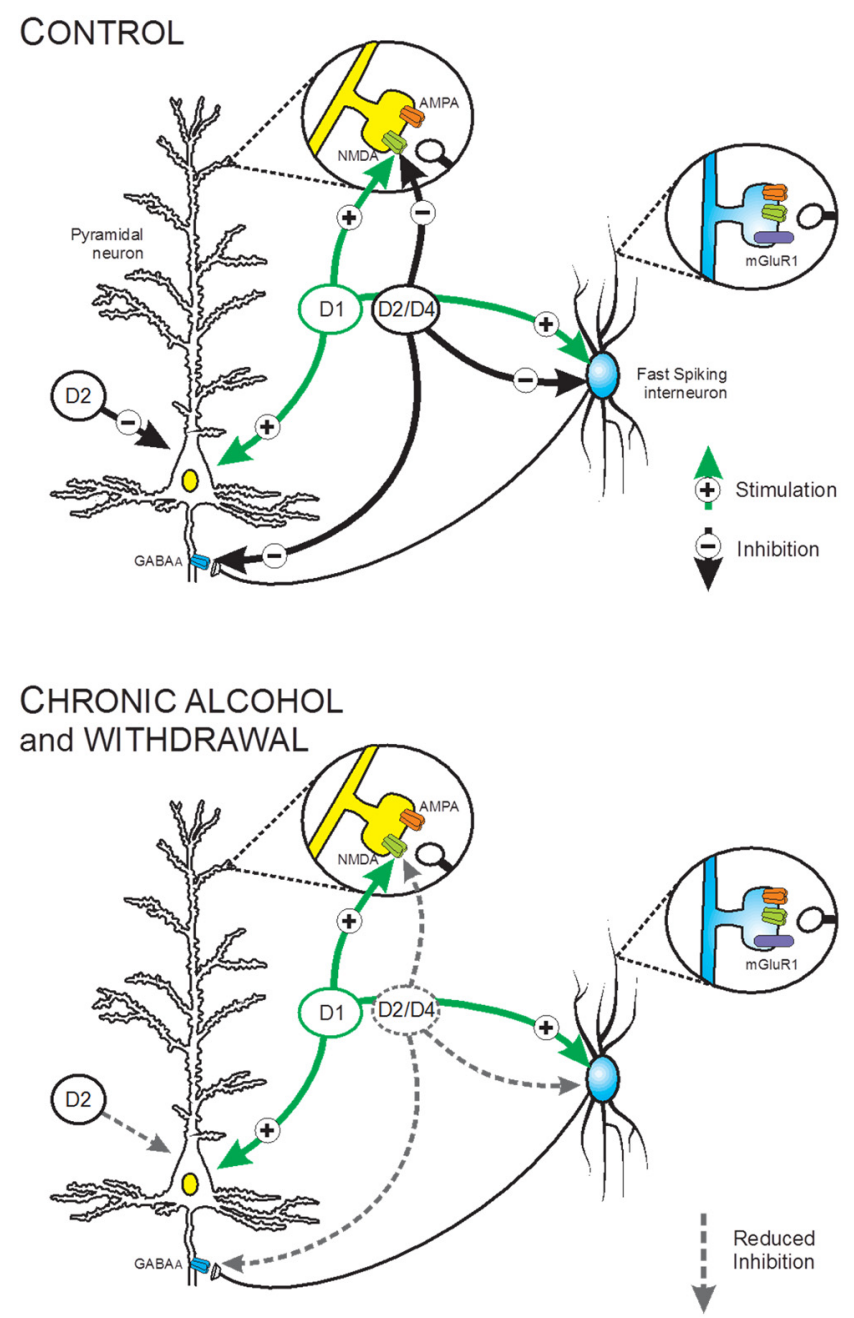

Figure 8. A schematic summary depicting the effects of CIE exposure on the intrinsic and synaptic actions of DA receptors on pyramidal neurons and FS interneurons in Layer 5 of the medial PFC. Top, Under control conditions, activation of D1 receptors enhanced the intrinsic firing of both cell types and facilitated glutamatergic neurotransmission by enhancing the activity of NMDA receptors but had no effect on AMPA currents. In contrast, D2 receptors inhibited the intrinsic firing of pyramidal and FS interneurons. D4 receptor stimulation had no effect on the intrinsic activity of pyramidal neurons but inhibited evoked firing of $\mathrm{FS}$ interneurons. Both D2 and D4 receptor stimulation inhibited synaptic NMDA and GABA $A_{A}$ currents on pyramidal neurons. Bottom, Following CIE exposure and withdrawal, D1 receptor-mediated responses were not affected whereas the modulatory actions of D2 and D4 receptors on intrinsic and synaptic activity were significantly attenuated. Also depicted is activation of $\mathrm{mGluR1}$ receptors enhances evoked firing of FS interneurons similar to D4 receptors, but this effect is not altered by CIE exposure. In light of the important role of FS interneurons on controlling and organizing prefrontal network activity, mGluR1 receptors may thus represent a novel pharmacological target to reverse the effects of CIE on the prefrontal cortex.

PFC. This is consistent with recent studies in mice that also used the CIE vapor exposure procedure and observed deficits in behavioral flexibility (Kroener et al., 2012) and fear extinction (Holmes et al., 2012).

In the PFC, layer V pyramidal neurons play two important roles in cognitive function. First, they integrate inputs from multiple brain regions and deliver output from the PFC to specific subcortical structures to direct behavioral responses. Second, recurrent excitatory activity between pyramidal neurons forms the cellular basis for maintenance of information within the network (Compte et al., 2000). Inhibitory GABAergic interneurons, especially the FS subtype, further tune and refine these networks to 
provide specificity over information flow (Rao et al., 1999). By regulating intrinsic cellular excitability and synaptic currents, DA modulates the balance between inhibitory and excitatory neurotransmission to optimally tune neural network activity (Gao and Goldman-Rakic, 2003; Paspalas and Goldman-Rakic, 2005). A model has been proposed in which activation of D1 receptors in the PFC favors network stability and activation of D2 receptors favors higher network flexibility (Durstewitz et al., 2000). Since CIE-exposed rats exhibited deficits in behavioral flexibility similar to those induced by disruption of PFC DA transmission (Floresco et al., 2006), we used the adult acute slice preparation to determine whether CIE exposure also altered the modulatory effects of DA receptors in the PFC. These studies revealed that pyramidal and FS interneurons in CIE-exposed rats exhibit a loss of $\mathrm{D} 2$ receptor modulation of both evoked firing and postsynaptic responses. In contrast, D1 receptor modulation was unaffected (Fig. 8). It is reasonable to infer that a loss of D2 receptor modulation of activity in the PFC would adversely impact the organization of neural networks and the executive functions they support, and thus may play an important role in cognitive deficits associated with chronic alcohol exposure.

Imaging and genetic linkage studies in humans have reported an association between D2 receptor expression and addiction. While much less is known about D4 receptors and addiction, D4 receptor polymorphisms have also been associated with alcoholism (Hutchison et al., 2002). Reductions in D2 receptors have been reported in alcoholics and cocaine, heroin, and methamphetamine abusers, suggesting that reductions in D2 receptor expression may be a common underlying process in addiction (Noble, 2000; Lee et al., 2009). In agreement with our observations, it was recently reported in rats that daily administration of cocaine results in loss of $\mathrm{D} 2$ receptor modulation of $\mathrm{GABA}_{\mathrm{A}}$ currents and evoked firing of FS interneurons (Kroener and Lavin, 2010). Brain imaging studies have also found that unaffected members of alcoholic families have higher levels of D2 receptors, while the affected members have reduced levels of D2 receptors. This has lead to the suggestion that either low or high levels of D2 receptors impart increased vulnerability or resistance, respectively, to developing alcoholism. While most studies of D2/D4 receptors in addiction have focused on their role in reward processing and motivation, alterations in their modulation of cognition may also contribute to the susceptibility to relapse in the abstinent alcoholic.

Our observations suggest that D4 receptors on FS interneurons activate signaling processes that decrease action potential duration. As was the case with D2 receptors, this modulatory activity was not observed in slices from CIE-exposed rats. FS interneurons are characterized by brief, nonaccommodating action potentials and high firing rate (Puig et al., 2008). The brevity of the action potential results from activation of Kv3 channels, which speed repolarization and (Erisir et al., 1999). Loss of Kv3 channels or their blockade with TEA in FS interneurons results in action potentials that are wider and have a reduced evoked frequency (Goldberg et al., 2005, 2011). In the PFC, parvalbuminexpressing interneurons stain positive for Kv3.1 and Kv3.2 subunit mRNA. Therefore, Kv3 currents that we recorded in FS interneurons may have represented a composite current from $\mathrm{Kv} 3.1$ and Kv3.2 since both are expressed in this neuronal population (Chow et al., 1999). Of potential importance for the actions of DA is the finding that the Kv3.2 subunit has an amino acid residue that is phosphorylated by protein kinase A (Moreno et al., 1995). Importantly, knock out of the Kv3.2 subunit is associated with impaired gamma oscillations that are critically important in the PFC for network organization (Harvey et al., 2012). Accordingly, optimal levels of $\mathrm{D} 4$ receptor stimulation in $\mathrm{mPFC}$ have been shown to improve cognitive performance (Zhang et al., 2004), and since the effects of D4 receptors on FS interneurons may play a particularly important role in modulating coherent oscillatory activity during periods of cognitive demand, loss of this modulation may contribute to chronic ethanol associated cognitive dysfunction.

Since we observed that CIE exposure dramatically attenuated D2/D4 signaling in the PFC, therapeutically targeting these receptors with agonists to restore function as a potential treatment of alcohol addiction and relapse would appear to have an inherent drawback as targeting these nonfunctional receptors may not be as effective as restoring the functional effect they modulate. We therefore sought an alternative receptor system that may have similar modulatory actions on network activity in the PFC yet is not altered by CIE exposure. Interestingly, two recent studies reported that stimulation of mGluR1/5 activates feedforward inhibition onto pyramidal neurons in the PFC (Sun and Neugebauer, 2011). We expanded on this finding by bath applying the mGluR1-positive allosteric modulator Ro67-7476 and recording from pyramidal neurons and FS interneurons. mGluR1 stimulation increased evoked firing significantly in FS cells and also decreased evoked firing of pyramidal neurons when applied alone, but this effect was blocked with coapplication of a $\mathrm{GABA}_{\mathrm{A}}$ antagonist. Therefore, while more extensive studies are needed to establish that the source of GABA in this case is from FS interneurons, this observation suggests that mGluR1 stimulation could be used to selectively enhance inhibitory neurons in the PFC and restore the effect of D4 receptor modulation on the network following CIE exposure (Fig. 8). A strength of this approach is that positive allosteric receptor modulation will only increase activity when glutamate is present, limiting the severity of side effects that are often observed with direct acting receptor agonists.

In summary, the present findings reveal that CIE exposure profoundly disrupts D2/D4 modulation of PFC neural activity and impairs executive functioning dependent on mesocortical DA transmission. Thus, perturbations in PFC D2 and D4 receptor function may represent a common mechanism through which various classes of addictive drugs can hamper aspects of cognitive control regulated by the frontal lobes, which in turn may contribute to the addiction process.

\section{References}

Arnsten AF, Cai JX, Murphy BL, Goldman-Rakic PS (1994) Dopamine D1 receptor mechanisms in the cognitive performance of young adult and aged monkeys. Psychopharmacology 116:143-151. CrossRef Medline

Beazely MA, Tong A, Wei WL, Van Tol H, Sidhu B, MacDonald JF (2006) D2-class dopamine receptor inhibition of NMDA currents in prefrontal cortical neurons is platelet-derived growth factor receptor-dependent. J Neurochem 98:1657-1663. CrossRef Medline

Bergman H, Engelbrektson K, Fransson A, Herlitz K, Hindmarsh T, Neiman J (1998) [Alcohol-induced cognitive impairment is reversible. Neuropsychological tests but not MRT show improvement after abstinence]. Lakartidningen 95:4228, 4231-4236. Medline

Beveridge TJ, Smith HR, Nader MA, Porrino LJ (2009) Abstinence from chronic cocaine self-administration alters striatal dopamine systems in rhesus monkeys. Neuropsychopharmacology 34:1162-1171. CrossRef Medline

Bice PJ, Liang T, Zhang L, Strother WN, Carr LG (2008) Drd2 expression in the high alcohol-preferring and low alcohol-preferring mice. Mamm Genome 19:69-76. CrossRef Medline

Blume LC, Bass CE, Childers SR, Dalton GD, Roberts DC, Richardson JM, Xiao R, Selley DE, Howlett AC (2013) Striatal CB1 and D2 receptors 
regulate expression of each other, CRIP1A and delta opioid systems. J Neurochem 124:808-820. CrossRef Medline

Campanella S, Petit G, Maurage P, Kornreich C, Verbanck P, Noël X (2009) Chronic alcoholism: insights from neurophysiology. Neurophysiol Clin 39:191-207. CrossRef Medline

Campanella S, Petit G, Verbanck P, Kornreich C, Noel X (2011) How cognitive assessment through clinical neurophysiology may help optimize chronic alcoholism treatment. Neurophysiol Clin 41:115-123. CrossRef Medline

Charney DA, Zikos E, Gill KJ (2010) Early recovery from alcohol dependence: factors that promote or impede abstinence. J Subst Abuse Treat 38:42-50. CrossRef Medline

Chow A, Erisir A, Farb C, Nadal MS, Ozaita A, Lau D, Welker E, Rudy B (1999) $\mathrm{K}(+)$ channel expression distinguishes subpopulations of parvalbuminand somatostatin-containing neocortical interneurons. J Neurosci 19:93329345. Medline

Compte A, Brunel N, Goldman-Rakic PS, Wang XJ (2000) Synaptic mechanisms and network dynamics underlying spatial working memory in a cortical network model. Cereb Cortex 10:910-923. CrossRef Medline

Cools R, D'Esposito M (2011) Inverted-U-shaped dopamine actions on human working memory and cognitive control. Biol Psychiatry 69:e113-25. CrossRef Medline

Durstewitz D, Seamans JK, Sejnowski TJ (2000) Dopamine-mediated stabilization of delay-period activity in a network model of prefrontal cortex. J Neurophysiol 83:1733-1750. Medline

Erisir A, Lau D, Rudy B, Leonard CS (1999) Function of specific K(+) channels in sustained high-frequency firing of fast-spiking neocortical interneurons. J Neurophysiol 82:2476-2489. Medline

Finn PR, Justus A, Mazas C, Steinmetz JE (1999) Working memory, executive processes and the effects of alcohol on Go/No-Go learning: testing a model of behavioral regulation and impulsivity. Psychopharmacology 146:465-472. CrossRef Medline

Floresco SB, Magyar O (2006) Mesocortical dopamine modulation of executive functions: beyond working memory. Psychopharmacology 188: 567-585. CrossRef Medline

Floresco SB, Magyar O, Ghods-Sharifi S, Vexelman C, Tse MT (2006) Multiple dopamine receptor subtypes in the medial prefrontal cortex of the rat regulate set-shifting. Neuropsychopharmacology 31:297-309. CrossRef Medline

Floresco SB, Block AE, Tse MT (2008) Inactivation of the medial prefrontal cortex of the rat impairs strategy set-shifting, but not reversal learning, using a novel, automated procedure. Behav Brain Res 190:85-96. CrossRef Medline

Gan L, Falzone TL, Zhang K, Rubinstein M, Baldessarini RJ, Tarazi FI (2004) Enhanced expression of dopamine D(1) and glutamate NMDA receptors in dopamine $\mathrm{D}(4)$ receptor knockout mice. J Mol Neurosci 22:167-178. CrossRef Medline

Gao WJ, Goldman-Rakic PS (2003) Selective modulation of excitatory and inhibitory microcircuits by dopamine. Proc Natl Acad Sci U S A 100: 2836-2841. CrossRef Medline

Gao WJ, Wang Y, Goldman-Rakic PS (2003) Dopamine modulation of perisomatic and peridendritic inhibition in prefrontal cortex. J Neurosci 23:1622-1630. Medline

Garzón M, Duffy AM, Chan J, Lynch MK, Mackie K, Pickel VM (2013) Dopamine $\mathrm{D}(2)$ and acetylcholine alpha7 nicotinic receptors have subcellular distributions favoring mediation of convergent signaling in the mouse ventral tegmental area. Neuroscience 252:126-143. CrossRef Medline

Goldberg EM, Watanabe S, Chang SY, Joho RH, Huang ZJ, Leondard CS, Rudy B (2005) Specific functions of synaptically localized potassium channels in synaptic transmission at the neocortical GABAergic fastspiking cell synapse. J Neurosci 25:5230-5235. CrossRef Medline

Goldberg EM, Jeong HY, Kruglikov I, Tremblay R, Lazarenko RM, Rudy B (2011) Rapid developmental maturation of neocortical FS cell intrinsic excitability. Cereb Cortex 21:666-682. CrossRef Medline

Haluk DM, Floresco SB (2009) Ventral striatal dopamine modulation of different forms of behavioral flexibility. Neuropsychopharmacology 34 : 2041-2052. CrossRef Medline

Harvey M, Lau D, Civillico E, Rudy B, Contreras D (2012) Impaired longrange synchronization of gamma oscillations in the neocortex of a mouse lacking Kv3.2 potassium channels. J Neurophysiol 108:827833. CrossRef Medline
Holmes A, Fitzgerald PJ, MacPherson KP, DeBrouse L, Colacicco G, Flynn SM, MasneufS, Pleil KE, Li C, Marcinkiewcz CA, Kash TL, Gunduz-Cinar O, Camp M (2012) Chronic alcohol remodels prefrontal neurons and disrupts NMDAR-mediated fear extinction encoding. Nat Neurosci 15: 1359-1361. CrossRef Medline

Hutchison KE, McGeary J, Smolen A, Bryan A, Swift RM (2002) The DRD4 VNTR polymorphism moderates craving after alcohol consumption. Health Psychol 21:139-146. CrossRef Medline

Kraschewski A, Reese J, Anghelescu I, Winterer G, Schmidt LG, Gallinat J, Finckh U, Rommelspacher H, Wernicke C (2009) Association of the dopamine D2 receptor gene with alcohol dependence: haplotypes and subgroups of alcoholics as key factors for understanding receptor function. Pharmacogenet Genomics 19:513-527. CrossRef Medline

Kroener S, Lavin A (2010) Altered dopamine modulation of inhibition in the prefrontal cortex of cocaine-sensitized rats. Neuropsychopharmacology 35:2292-2304. CrossRef Medline

Kroener S, Mulholland PJ, New NN, Gass JT, Becker HC, Chandler LJ (2012) Chronic alcohol exposure alters behavioral and synaptic plasticity of the rodent prefrontal cortex. PLoS One 7:e37541. CrossRef Medline

Lee B, London ED, Poldrack RA, Farahi J, Nacca A, Monterosso JR, Mumford JA, Bokarius AV, Dahlbom M, Mukherjee J, Bilder RM, Brody AL, Mandelkern MA (2009) Striatal dopamine $\mathrm{d} 2 / \mathrm{d} 3$ receptor availability is reduced in methamphetamine dependence and is linked to impulsivity. J Neurosci 29:14734-14740. CrossRef Medline

Lewis DA, Sesack SR, Levey AI, Rosenberg DR (1998) Dopamine axons in primate prefrontal cortex: specificity of distribution, synaptic targets, and development. Adv Pharmacol 42:703-706. Medline

Moreno H, Kentros C, Bueno E, Weiser M, Hernandez A, Vega-Saenz de Miera E, Ponce A, Thornhill W, Rudy B (1995) Thalamocortical projections have a $\mathrm{K}+$ channel that is phosphorylated and modulated by cAMPdependent protein kinase. J Neurosci 15:5486-5501. Medline

Morganstern I, Tejani-Butt S (2010) Differential patterns of alcohol consumption and dopamine-2 receptor binding in Wistar-Kyoto and Wistar rats. Neurochem Res 35:1708-1715. CrossRef Medline

Mulholland PJ, Becker HC, Woodward JJ, Chandler LJ (2011) Small conductance calcium-activated potassium type 2 channels regulate alcoholassociated plasticity of glutamatergic synapses. Biol Psychiatry 69:625-632. CrossRef Medline

Myrick H, Anton R, Voronin K, Wang W, Henderson S (2007) A doubleblind evaluation of gabapentin on alcohol effects and drinking in a clinical laboratory paradigm. Alcohol Clin Exp Res 31:221-227. CrossRef Medline

Nixon K, Crews FT (2002) Binge ethanol exposure decreases neurogenesis in adult rat hippocampus. J Neurochem 83:1087-1093. CrossRef Medline

Noble EP (2000) Addiction and its reward process through polymorphisms of the D2 dopamine receptor gene: a review. Eur Psychiatry 15:79-89. CrossRef Medline

O'Dell LE, Roberts AJ, Smith RT, Koob GF (2004) Enhanced alcohol selfadministration after intermittent versus continuous alcohol vapor exposure. Alcohol Clin Exp Res 28:1676-1682. CrossRef Medline

Paspalas CD, Goldman-Rakic PS (2005) Presynaptic D1 dopamine receptors in primate prefrontal cortex: target-specific expression in the glutamatergic synapse. J Neurosci 25:1260-1267. CrossRef Medline

Paxinos G, Watson P (2007) The rat brain in stereotaxic coordinates, 6th edition. San Diego: Elsevier.

Prencipe L, Iaccheri E, Manzati C (1987) Enzymic ethanol assay: a new colorimetric method based on measurement of hydrogen peroxide. Clin Chem 33:486-489. Medline

Puig MV, Ushimaru M, Kawaguchi Y (2008) Two distinct activity patterns of fast-spiking interneurons during neocortical UP states. Proc Natl Acad Sci U S A 105:8428-8433. CrossRef Medline

Rando K, Hong KI, Bhagwagar Z, Li CS, Bergquist K, Guarnaccia J, Sinha R (2011) Association of frontal and posterior cortical gray matter volume with time to alcohol relapse: a prospective study. Am J Psychiatry 168: 183-192. CrossRef Medline

Rao SG, Williams GV, Goldman-Rakic PS (1999) Isodirectional tuning of adjacent interneurons and pyramidal cells during working memory: evidence for microcolumnar organization in PFC. J Neurophysiol 81:19031916. Medline

Richardson NR, Roberts DC (1996) Progressive ratio schedules in drug selfadministration studies in rats: a method to evaluate reinforcing efficacy. J Neurosci Methods 66:1-11. CrossRef Medline 
Rudy B, Chow A, Lau D, Amarillo Y, Ozaita A, Saganich M, Moreno H, Nadal MS, Hernandez-Pineda R, Hernandez-Cruz A, Erisir A, Leonard C, VegaSaenz de Miera E (1999) Contributions of Kv3 channels to neuronal excitability. Ann N Y Acad Sci 868:304-343. CrossRef Medline

Sabia S, Guéguen A, Berr C, Berkman L, Ankri J, Goldberg M, Zins M, SinghManoux A (2011) High alcohol consumption in middle-aged adults is associated with poorer cognitive performance only in the low socioeconomic group. Results from the GAZEL cohort study. Addiction 106: 93-101. CrossRef Medline

Schacht JP, Randall PK, Waid LR, Baros AM, Latham PK, Wright TM, Myrick H, Anton RF. (2011) Neurocognitive performance, alcohol withdrawal, and effects of a combination of flumazenil and gabapentin in alcohol dependence. Alcohol Clin Exp Res 35:2030-2038. CrossRef Medline

Sim LJ, Selley DE, Childers SR (1995) In vitro autoradiography of receptoractivated $G$ proteins in rat brain by agonist-stimulated guanylyl 5'[gamma-[35S]thio]-triphosphate binding. Proc Natl Acad Sci U S A 92: 7242-7246. CrossRef Medline

Sullivan EV, Rosenbloom MJ, Pfefferbaum A (2000) Pattern of motor and cognitive deficits in detoxified alcoholic men. Alcohol Clin Exp Res 24: 611-621. CrossRef Medline

Sun H, Neugebauer V (2011) mGluR1, but not mGluR5, activates feedforward inhibition in the medial prefrontal cortex to impair decision making. J Neurophysiol 106:960-973. CrossRef Medline

Tedstone D, Coyle K (2004) Cognitive impairments in sober alcoholics: performance on selective and divided attention tasks. Drug Alcohol Depend 75:277-286. CrossRef Medline

Trantham-Davidson H, Kröner S, Seamans JK (2008) Dopamine modulation of prefrontal cortex interneurons occurs independently of DARPP32. Cereb Cortex 18:951-958. CrossRef Medline

Tseng KY, O’Donnell P (2007) Dopamine modulation of prefrontal cortical interneurons changes during adolescence. Cereb Cortex 17:1235-1240. Medline

van der Zwaluw CS, Kuntsche E, Engels RC (2011) Risky alcohol use in adolescence: the role of genetics (DRD2, SLC6A4) and coping motives. Alcohol Clin Exp Res 35:756-764. CrossRef Medline

Volkow ND, Wang GJ, Fowler JS, Logan J, Hitzemann R, Ding YS, Pappas N, Shea C, Piscani K (1996) Decreases in dopamine receptors but not in dopamine transporters in alcoholics. Alcohol Clin Exp Res 20:1594-1598. CrossRef Medline

Volkow ND, Wang GJ, Maynard L, Fowler JS, Jayne B, Telang F, Logan J, Ding YS, Gatley SJ, Hitzemann R, Wong C, Pappas N (2002) Effects of alcohol detoxification on dopamine D2 receptors in alcoholics: a preliminary study. Psychiatry Res 116:163-172. CrossRef Medline

Volkow ND, Wang GJ, Begleiter H, Porjesz B, Fowler JS, Telang F, Wong C, Ma Y, Logan J, Goldstein R, Alexoff D, Thanos PK (2006) High levels of dopamine D2 receptors in unaffected members of alcoholic families: possible protective factors. Arch Gen Psychiatry 63:999-1008. CrossRef Medline

Wang X, Zhong P, Gu Z, Yan Z (2003) Regulation of NMDA receptors by dopamine D4 signaling in prefrontal cortex. J Neurosci 23:9852-9861. Medline

Wicks S, Hammar J, Heilig M, Wisén O (2001) Factors affecting the shortterm prognosis of alcohol dependent patients undergoing inpatient detoxification. Subst Abus 22:235-245. CrossRef Medline

Wölwer W, Burtscheidt W, Redner C, Schwarz R, Gaebel W (2001) Outpatient behaviour therapy in alcoholism: impact of personality disorders and cognitive impairments. Acta Psychiatr Scand 103:30-37. CrossRef Medline

Zhang K, Grady CJ, Tsapakis EM, Andersen SL, Tarazi FI, Baldessarini RJ (2004) Regulation of working memory by dopamine D4 receptor in rats. Neuropsychopharmacology 29:1648-1655. CrossRef Medline 